\title{
Determination of Heavy Metals and Polychlorinated Biphenyls in Oncological Patients: A Pilot Study
}

\author{
V Petrosino ${ }^{1 *}$, M Coletta ${ }^{2}$ and D Testa ${ }^{2}$ \\ ${ }^{1}$ ASL Salerno, International Society of Doctors for the Environment (ISDE) , Salerno, Italy
}

${ }^{2}$ ENT Clinic, University of Naples, via S. Pansini, 5,80131 Naples, Italy

Received: August 21, 2019; Accepted: September 30, 2019; Published: October 03, 2019

*Corresponding author: Petrosino Vincenzo, ASL Salerno, International Society of Doctors for the Environment (ISDE) , Salerno, Italy, E-mail: petrosino8@virgilio.it

\begin{abstract}
A large number of studies in the literature increasingly suggest a causal relationship between the onset of cancer and other diseases and the exposure to environmental pollutants, particularly heavy metals, polychlorinated biphenyls (PCBs) and other products. Environmental pollution seems to be an important determinant for the onset of several diseases, so special attention must be paid to this question.
\end{abstract}

Recently, some authors, by measuring heavy metals in cancer tissue, have come to the conclusion that these metals can accumulate in tumor tissue and, through different mechanisms and actions, can stimulate the progression of breast cancers and reduce the sensitivity to various treatments.

In this study, in order to investigate the involvement of these pollutants in the development of certain types of cancer, we measured the levels of 14 heavy metals in blood and hair samples, and 12 PCBs in blood samples of a total of 33 cancer patients living in areas considered at risk of pollution.

All studied patients were found to have variable amounts of heavy metals and some PCBs especially in the blood.

The exact mechanism by which these substances affect the various stages of the neoplastic process is still the subject of our investigation.

In our study, metal levels were found to be at least three times higher than the maximum reference value in all patients.

Key Words: Heavy Metals; Polychlorinated Biphenyls (PCBs); Pollution; Cancer

\section{Introduction}

An increasing number of studies worldwide attribute great importance to environmental pollution, which can be quite simply defined as any undesirable change in physical, chemical, or biological characteristics of air, water and soil.

In the last hundred years, humans have produced - in the name of so-called 'progress' - substances that do not exist in nature (and that have often been disposed of in the environment, either intentionally or negligently), by increasing industrial production with high levels of emissions, increasing transport by road and by plane, and producing all types of emissions derived from combustion processes.
The environment is the surroundings in which we live and with which we continuously interact. Everyone has a very close relationship with the environment from which we can get any kind of noxae that, acting in different ways on our body, can cause - through various mechanisms, often still unknown - a number of short-, medium- and long-term changes.

A large number of studies in the literature increasingly suggest a causal relationship between the onset of cancer and other diseases and the exposure to environmental pollutants, particularly heavy metals, polychlorinated biphenyls (PCBs) and other products.

Recently, some authors, by measuring heavy metals in cancer tissue, have come to the conclusion that these metals can accumulate in tumor tissue and, through different mechanisms and actions, stimulate the progression of breast cancers and reduce the sensitivity to various treatments [1].

These metallic substances induce oxidative stress and can bind to DNA, leading to DNA damage, inhibition of DNA repair, and cell death, resulting in an increased risk of cancer and cancerrelated diseases. One of the most important mechanisms is the production of free radicals and, in particular, the generation of reactive oxigen species (ROS), including the hydroxyl radical (HO), the superoxide radical $\left(\mathrm{O}_{2}^{-}\right)$, and hydrogen peroxide $\left(\mathrm{H}_{2} \mathrm{O}_{2}\right)$. There are various types and systems of intracellular antioxidants, including glutathione (GSH), heme oxygenase 1 (HO-1), and superoxide dismutase (SOD). Phytochemical substances, which include carotenoids and flavonoids, are also important antioxidants. They are found in large quantities in fruits and vegetables, and therefore their regular ingestion helps reduce damage from oxidative stress [2].

PCBs are persistent pollutants and, by mimicking, interfering or blocking the functions of hormones, can alter the risk of a number of cancers, including breast cancer [3]. Heavy metals, PCBs and other substances may be present in many critical environmental settings, and especially in areas where waste has been intentionally or negligently discarded.

The toxicity and carcinogenicity of these substances is well known. They tend to bioaccumulate in the body, and many of them can act as endocrine disruptors [4] or have subtle effects 
on DNA. The true relationship between the extent of exposure to these substances and the onset of cancer is still a subject of active research $[1,5]$. It is also extremely difficult to understand how multiple chemical substances can interact with each other, and with the human body $[6,7]$.

PCBs, synthesized at the beginning of the last century, have been produced through industrial processes; they are very stable compounds, poorly soluble in water, and are derived from crude oil and coal tar. They have been used in countless industrial applications [4]. They were used in the past as oil insulators for electrical transformers and capacitors. They were also used as hydraulic fluids, oil additives to paints, sealants, glues, additives to pesticides, sheaths for electric conductors, printing inks, photocopying papers, carbon papers, and for the production of many synthetic fibers $[7,8]$. They can also be generated by waste incineration, especially by burning PCBs-containing oils. Many PCBs have been banned since 1985, but they are still present in landfills, as well as in many products of frequent use, resulting in a ubiquitous, poorly controlled, severe form of pollution.

These PCBs have been produced in millions of tons and can be found almost everywhere, even in marine sediments and rivers, although they enter the body mainly through the ingestion of contaminated food and water $[7,8]$. These substances also have the capacity to bioaccumulate $[7,8]$, and have been considered carcinogenic to humans by the International Agency for Research on Cancer (IARC) [8-10].

Some PCBs can act on the arylhydrocarbon (AhR) receptor and on the immune system by stimulating the response of inflammatory mediators, and can also function as endocrine disruptors, in addition to exerting genotoxic effects [11].

Heavy metals do not have a universally accepted definition, but they typically include most metals with an atomic number greater than 20 or a density greater than $5 \mathrm{~g} / \mathrm{cm}^{3}$ [12]. Heavy metals are pollutants that, although present in very low concentrations, can lead to a wide range of adverse effects on the environment and on people's health. They can be found in the air, water, or food, and are often distributed in the atmosphere and soil as a consequence of industrial activities: some metals are essential -i.e., they are required by our body- but in high concentrations may have toxic effects (chromium, iron, copper and zinc), while others do not seem to play any role in vital processes (aluminum, nickel, arsenic, cadmium, mercury and lead) [2, 10]. They are byproducts of incinerators, burning of gasoline and diesel fuel (cars, trucks, airplanes, ships, etc.), foundries, paints, insecticides, and agriculture products such as disinfectants [13], and can be absorbed by inhalation, ingestion, or even skin contact, although in lesser amount. At high concentrations, any of these metals can cause acute intoxication, affecting multiple organs and systems. Many of these metals have been classified as definite or probable carcinogens by the IARC: for example, arsenic, beryllium, cadmium, chromium and nickel are considered carcinogenic $[9,11]$.

Several studies in the literature have emphasized the molecular toxicity mechanisms induced by specific substances, such as arsenic, cadmium, chromium, nickel, lead, and barium; according to IARC, the damage may occur through oxidative stress, DNA changes (also caused by epigenetic stress), and as a consequence of their ability to function as endocrine disruptors $[14,15]$. The exposure of the population to chemical agents in the environment and food is a major concern for health institutions. It is desirable to start measuring these substances in both sick and healthy individuals, and not only in the environment or in food, in order to detect their presence and possible correlation with a variety of diseases in the local population.

\section{Objectives}

The aim of the study was to ascertain the presence of heavy metals and PCBs in the blood and hair of patients with neoplastic diseases, who had been living for at least 10 years in certain geographical areas of Campania and Basilicata, i.e., areas declared at risk, or potentially at risk of environmental pollution.

We measured a total of 14 metals (aluminum, antimony, arsenic, barium, cadmium, chromium, iron, lithium, mercury, nickel, lead, copper, strontium and zinc) in the blood and hair of patients with cancer, as well as 12 PCBs

3,4,4',5-tetrachlorobiphenyl; 3, 3',4,4'-tetrachlorobiphenyl; 2'3,4,4',5-pentachlorobiphenyl; 2,3',4,4',5-pentachlorobiphenyl; 2,3,4,4',5-pentachlorobiphenyl; 2,3,3',4,4'-pentachlorobiphenyl; 3,3'4,4',5-pentachlorobiphenyl; 2,3'4,4',5,5'-hexachlorobiphenyl; 2,3,3',4,4',5-hexachlorobiphenyl; 2,3,3',4,4',5'-hexachlorobiphenyl; 3,3'4,4',5,5'-hexachlorobiphenyl; 2,3,3',4,4',5,5'-eptachlorobiphenyl; in the blood [Table 2].

In this study, we evaluated the presence and quantity of heavy metals in two different biological matrices (blood and hair) and PCBs in the blood. We correlated these biochemical data with the cancer conditions as well as the place of residence of the patients.

The research was carried out on a sample of volunteers with tumors in different body sites.

In a previous pilot study of 20 volunteers, we already reported the presence of heavy metals and PCBs in patients with head and neck tumors and thyroid disorders [16].

\section{Materials and Methods}

All volunteers were made aware of the aim of the study and provided their written informed consent for participation in this study. A detailed medical history was taken from all patients, including medications taken, place of usual residence [Table 1], years of residence, and any major environmental concerns in that area. Medical records and all histopathological reports were also acquired. Quali-quantitative determinations of the 14 heavy metals were performed on capillary blood samples and on hair samples taken from the nuchal region, while measurements of the 12 PCBs were taken on blood samples.

Blood and hair samples were taken during the patient's stay in the hospital, where they underwent diagnostic and therapeutic procedures based on their specific disease condition.

Blood and hair samples (0.5 g) underwent acid digestion with 
$\mathrm{H}_{2} \mathrm{SO}_{4}$ in a Ethos One microwave digester for $10 \mathrm{~min}$ at $\mathrm{T}=200$ ${ }^{\circ} \mathrm{C}$, and power $=1000 \mathrm{~W}$. The digested sample was added with $5 \mathrm{~mL}$ of $\mathrm{HNO}_{3}$ and $2 \mathrm{~mL}$ of $\mathrm{H}_{2} \mathrm{O}_{2}$, followed by mineralization in a microwave digestion system for $20 \mathrm{~min}$ at $\mathrm{T}=200^{\circ} \mathrm{C}$, and power $=1000 \mathrm{~W}$. The mineralized sample $(1 \mathrm{ml})$ was added with $20 \mu \mathrm{l}$ of palladium matrix modifier to make the matrix more volatile and the analyte less volatile.

Analyses were then performed by atomic absorption spectroscopy (Shimadzu AA-6300) with atomization in a graphite furnace, with the amounts of each element expressed in $\mu \mathrm{g} / 100$ g of sample.

PCBs were measured, after liquid-liquid extraction with n-hexane/dichloromethane mixture, pre-purification by partition with acetonitrile, sulfur elimination, and purification/fractionation by silica gel chromatography. Final analyses were performed by gas chromatography-mass spectrometry (GC-MS). All analyses on blood and hair samples were performed at the Department of Pharmacy of the University "Federico II" of Naples.

\section{Results}

The results of the analyses, expressed in $\mu \mathrm{g} / \mathrm{l}$ in blood and in $\mu \mathrm{g} / \mathrm{g}$ of hair for the 14 metals, and in $\mathrm{pg} / \mathrm{ml}$ for the PCBs, were evaluated according to the reference tables provided by the ISTISAN [Table 3] and WHO-2005 reports.

The results of the analyses of 33 patients with neoplastic diseases demonstrate that, in all patients, detected levels of most heavy metals were several units higher (up to 4-5 times) than the upper reference limits. The levels of the 12 PCBs in the blood showed - for some tumors - positive values higher than the maximum reference values (although there is no clear table reference values according to the WHO-2005 reports).

Some heavy metals and PCBs are constantly present in certain types of cancer; the regular presence of 2,3,4,4',5-pentachlorobiphenyl and 2,3',4,4',5-pentachlorobiphenyl in many sick volunteers is almost typical.

The findings from the analysis performed on 33 cancer patients demonstrate the following.

Increased levels of aluminum, arsenic, cadmium, mercury, nickel and lead were found in 10 patients with breast cancer (patients' \#1-10 of Table 1). Chromium and antimony were present in 8 cases, but were absent in two patients, one with ductal carcinoma and the other with ductal carcinoma and Hodgkin's lymphoma.

In the hair samples of seven patients, we found high levels of chromium, with high levels of PCBs in 6 of them. As for PCBs, 7 patients had higher than normal values of 2,3'4,4',5-pentachlorobiphenyl, with 3 patients also having higher than normal values of 2',3,4,4' 5-pentachlorobiphenyl.

In 3 patients with carcinoma of the stomach (patients \#13-15 of Table 1), we found the presence of higher than normal blood levels of aluminum, zinc, strontium, lead and copper in all of them. High levels of arsenic, cadmium, chromium, mercury and nickel were present only in two of these patients. In the hair samples, we found higher than normal levels of chromium in all three subjects, as well as higher levels of lead in two patients.

Three patients had higher than normal levels of 2',3,4,4',5-pentachlorobiphenyl, and two patients also had higher levels of 2,3,4,4,5-pentachlorobiphenyl.

High levels of aluminum, antimony, arsenic, cadmium, chromium, mercury, nickel and lead were detected in the capillary blood of a patient with rectal carcinoma and bladder cancer (patient \#11 of table 1). High levels of arsenic, cadmium, chromium and nickel were also found in the hair. As for PCBs, the levels of 2,3,4,4,5- pentachlorobiphenyl, 2,3',4,4',5-pentachlorobiphenyl, 2,3,4,4',5-pentachlorobiphenyl, and 2,3,3',4,4',5'-hexachlorobiphenyl were high in this patient. Also the levels of arsenic, cadmium, chromium and nickel were high in the hair of this patient.

The patient suffering not only from rectal cancer, but also from papillary thyroid carcinoma and Hodgkin's lymphoma (patient \#19 of Table 1), had high levels of 10 heavy metals: aluminum, antimony, arsenic, cadmium, chromium, mercury, nickel, lead, copper, and zinc, as well as chromium in the hair. This patient had higher than normal levels of 2,3,4,4',5- pentachlorobiphenyl and 2,3,3',4,4'5'-hexachlorobiphenyl.

The 2 patients with laryngeal carcinoma (patients \#24 and \#25 of Table 1) (a 57-year-old female patient with G2-G3 squamous cell carcinoma of the vocal cords, and a 70-year-old patient with squamous cell carcinoma of the epiglottis) had high levels of the same heavy metals in the blood (aluminum, antimony, arsenic, cadmium, chromium, mercury, nickel, lead, copper, zinc), as well as high levels of the same PCBs in the blood $\left(2,3,4,4,5-, 2,3^{\prime}, 4,4,5-\right.$, and 2,3,4,4',5-pentachlorobiphenyl). They also had the same heavy metals in the hair: arsenic, cadmium, chromium and lead.

The patient with nasopharyngeal carcinoma had higher levels of aluminum, antimony, barium, nickel, and lead in the blood, as well as increased levels of arsenic, cadmium, and chromium in the hair. However, only the blood level of 2,3',4,4,'5-pentachlorobiphenyl was found to be elevated just above the normal range.

The patient with tonsillar non-Hodgkin's lymphoma, mantle-cell type (patient \#27 of Table 1), had high levels of heavy metals in the blood, i.e. aluminum, antimony, arsenic, cadmium, chromium, mercury, nickel, lead and copper, similarly to the patients with laryngeal carcinoma, as well as high levels of the following PCBs in the blood: 2',3,4,4',5-pentachlorobiphenyl, 2,3,4,4',5-pentachlorobiphenyl, and 2,3,3',4,4',5'-hexachlorobiphenyl.

The 3 patients with thyroid carcinoma only (patients \#28, \#29 and \#30 of Table 1), including both papillary and follicular varieties, had commonly - and to a similar extent - high levels of aluminum, cadmium, mercury, nickel, and lead in the blood. The level of chromium in the hair was about three times higher, except in a case of papillary carcinoma which showed a level of chromium close to the maximum limit, and a two times higher level of arsenic. In all 3 cases we found high levels of 2,3,4,4',5-pentachlorobiphenyl 
and 2,3',4,4',5- pentachlorobiphenyl in the blood.

In the three patients with testicular carcinoma (2 seminomas and an embryonic carcinoma) (patients \#16, \#17 and \#18 of Table 1), we found high levels of aluminum, antimony, arsenic, cadmium, chromium, mercury, nickel, lead and zinc. In the two patients with seminoma, chromium was present in the hair. In all three patients, we found the presence of 2',3,4,4',5-pentachlorobiphenyl.

\begin{tabular}{|c|c|c|c|c|c|}
\hline ID & GENDER & AGE & DISEASE & PROVINCE & PLACE OF RESIDENCE \\
\hline 1 & $\mathrm{~F}$ & 47 & DUCTAL BREAST CARCINOMA & NAPLES & Giugliano \\
\hline 2 & $\mathrm{~F}$ & 50 & DUCTAL BREAST CARCINOMA & NAPLES & Qualiano \\
\hline 3 & $\mathrm{~F}$ & 33 & DUCTAL BREAST CARCINOMA & POTENZA & Lavello \\
\hline 4 & $\mathrm{~F}$ & 44 & DUCTAL BREAST CARCINOMA & NAPLES & Naples \\
\hline 5 & $\mathrm{~F}$ & 50 & $\begin{array}{l}\text { MUCINOUS AND LOBULAR DUCTAL BREAST } \\
\text { CARCINOMA }\end{array}$ & NAPLES & Quarto \\
\hline 6 & $\mathrm{~F}$ & 60 & $\begin{array}{l}\text { DUCTAL BREAST CARCINOMA AND } \\
\text { HODGKIN LYMPHOMA }\end{array}$ & NAPLES & Villaricca \\
\hline 7 & $\mathrm{~F}$ & 60 & $\begin{array}{l}\text { DUCTAL BREAST CARCINOMA AND BONE } \\
\text { METASTASIS }\end{array}$ & CASERTA & Sessa Aurunca \\
\hline 8 & $\mathrm{~F}$ & 50 & DUCTAL BREAST CARCINOMA & POTENZA & Palazzo San Gervasio \\
\hline 9 & $\mathrm{~F}$ & 58 & DUCTAL BREAST CARCINOMA & NAPLES & Qualiano \\
\hline 10 & $\mathrm{~F}$ & 50 & MULTIFOCAL BREAST CARCINOMA & POTENZA & Potenza \\
\hline 11 & M & 59 & RECTAL AND BLADDER CARCINOMA & NAPLES & Naples \\
\hline 12 & M & 66 & APPENDIX CARCINOMA & NAPLES & Casoria \\
\hline 13 & M & 63 & GASTRIC CANCER - ADENOCARCINOMA & CASERTA & Casapenna \\
\hline 14 & $\mathrm{~F}$ & 59 & $\begin{array}{l}\text { GASTRIC CANCER - SIGNET RING CELL } \\
\text { CARCINOMA }\end{array}$ & SALERNO & Salerno \\
\hline 15 & $\mathrm{~F}$ & 55 & GASTRIC CANCER - ADENOCARCINOMA & POTENZA & Lavello \\
\hline 16 & M & 48 & TESTICULAR SEMINOMA & NAPLES & Giugliano \\
\hline 17 & M & 51 & TESTICULAR SEMINOMA & NAPLES & Aversa \\
\hline 18 & M & 42 & $\begin{array}{c}\text { TESTICULAR EMBRYONAL CARCINOMA } \\
\text { AND HODGKIN LYMPHOMA }\end{array}$ & NAPLES & Naples \\
\hline 19 & M & 39 & $\begin{array}{c}\text { RECTAL CANCER - PAPILLARY CANCER - } \\
\text { HODGKIN LYMPHOMA }\end{array}$ & NAPLES & Acerra \\
\hline 20 & M & 26 & $\begin{array}{l}\text { MEDIASTINAL NON-SEMINOMATOUS GERM } \\
\text { CELL TUMOR }\end{array}$ & NAPLES & Frattamaggiore \\
\hline 21 & $\mathrm{~F}$ & 6 & LYMPHOBLASTIC LEUKEMIA & NAPLES & Giugliano \\
\hline 22 & $\mathrm{~F}$ & 54 & MYELOID LEUKEMIA & POTENZA & Potenza \\
\hline 23 & M & 31 & HODGKIN LYMPHOMA & NAPLES & Casoria \\
\hline 24 & $\mathrm{~F}$ & 57 & LARYNGEAL CARCINOMA & NAPLES & Naples \\
\hline 25 & M & 70 & LARYNGEAL CARCINOMA & NAPLES & Naples \\
\hline 26 & $\mathrm{~F}$ & 46 & NASOPHARYNGEAL CARCINOMA & NAPLES & Naples \\
\hline 27 & M & 73 & $\begin{array}{c}\text { TONSILLAR NON-HODGKIN MANTLE CELL } \\
\text { LYMPHOMA }\end{array}$ & NAPLES & Frignano \\
\hline 28 & M & 23 & PAPILLARY THYROID CARCINOMA & SALERNO & Cava dei Tirreni \\
\hline 29 & $\mathrm{~F}$ & 47 & PAPILLARY THYROID CARCINOMA & NAPLES & Aversa \\
\hline 30 & $\mathrm{~F}$ & 65 & FOLLICULAR THYROID CARCINOMA & NAPLES & Casalnuovo \\
\hline 31 & M & 65 & RENAL CARCINOMA & POTENZA & Senise \\
\hline 32 & $\mathrm{~F}$ & 31 & ONCOCYTOMA - RENAL CARCINOMA & POTENZA & Brienza \\
\hline 33 & $\mathrm{~F}$ & 65 & $\begin{array}{l}\text { OVARIAN CANCER AND PERITONEAL } \\
\text { METASTASIS }\end{array}$ & POTENZA & Orta di Atella \\
\hline
\end{tabular}


The 2 patients with lymphatic leukemia and myeloid leukemia (patients \#21 and \#22 of Table 1) had higher than normal levels of aluminum, antimony, arsenic, cadmium, chromium, mercury, nickel, lead, copper and zinc. The patient with lymphoblastic leukemia also had high levels of chromium in the hair. Only the patient with myeloid leukemia had higher levels of strontium in the blood. Both patients showed increased levels of 2',3,4,4',5-pentachlorobiphenyl compared to the reference value. Only the patient with lymphoblastic leukemia had higher than normal levels of 2,3',4,4',5-pentachlorobiphenyl and 2,3,4,4',5-pentachlorobiphenyl in the blood.

Of the 4 patients with Hodgkin's lymphoma (patients \#6, \#18, \#19 and \#23 of Table 1), three also had other cancers (Hodgkin + breast cancer; Hodgkin + testicular seminoma; Hodgkin + papillary thyroid cancer + rectal cancer). All patients had higher than normal levels of aluminum, arsenic, cadmium, mercury, nickel, lead and zinc. No chromium was found in the only patient with mammary ductal carcinoma and Hodgkin's lymphoma. Chromium levels about 3 times higher than the maximum table value were found in three patients, specifically in a patient with rectal cancer and thyroid cancer, a patient with testicular seminoma, and a patient with lymphoma only.

Inall 3 patientswithlymphomaassociated with otherneoplasms, we found higher levels of 2,3,3',4,4',5'-hexachlorobiphenyl, as well as increased levels of 2,3',4,4,5- pentachlorobiphenyl in two patients (in the patient with rectal cancer + thyroid cancer + lymphoma, and in the patient with lymphoma + breast cancer). We did not detect pathological levels of PCBs in the patient with nodular sclerosis lymphoma only.

\begin{tabular}{|c|c|}
\hline \multicolumn{1}{|l|}{ Table 2 } \\
\hline Polychlorobiphenyls (blood) & WHO-TE (pg/mL) \\
\hline $3,4,4^{\prime}, 5$-tetrachlorobiphenyl & na \\
\hline $3,3^{\prime}, 4,4^{\prime}$-tetrachlorobiphenyl & na \\
\hline $2^{\prime} 3,4,4^{\prime}, 5$-pentachlorobiphenyl & 0.00018 \\
\hline $2,3^{\prime}, 4,4^{\prime}, 5$-pentachlorobiphenyl & 0.01571 \\
\hline $2,3,4,4^{\prime}, 5$-pentachlorobiphenyl & 0.0059 \\
\hline $2,3,3^{\prime}, 4,4^{\prime}$-pentachlorobiphenyl & 0.00308 \\
\hline $3,3^{\prime}, 4,4^{\prime}, 5$-pentachlorobiphenyl & 0.1 \\
\hline $2,3^{\prime} 4,4^{\prime}, 5,5$-hexachlorobiphenyl & 0.000436 \\
\hline $2,3,3^{\prime}, 4,4^{\prime}, 5$-hexachlorobiphenyl & 0.06675 \\
\hline $2,3,3^{\prime}, 4,4^{\prime}, 5^{\prime}$-hexachlorobiphenyl & 0.0131 \\
\hline $3,3^{\prime}, 4,4^{\prime}, 5,5^{\prime}$ '-hexachlorobiphenyl & 0.008 \\
\hline $2,3,3^{\prime}, 4,4^{\prime}, 5,5^{\prime}$-heptachlorobiphenyl & 0.00179 \\
\hline *Toxicities calculated using the WHO-2005-TEF values \\
\hline na: not available. \\
\hline Limit of Detection (LoD) \\
\hline
\end{tabular}

The patient with appendix carcinoma (patient 12 of Table 1) showed high levels of aluminum, antimony, arsenic, cadmium, chromium, mercury, nickel and copper. In the hair, we detected arsenic at a level twice the maximum reference value, as well as high levels of lead and chromium. Regarding PCBs, we found the presence of 2,3,3',4,4',5'-hexachlorobiphenyl.

The patient with mediastinal tumor (patient \#20 of Table 1) had higher than normal levels of aluminum, antimony, cadmium, chromium, mercury, nickel, lead and zinc. The metals in the hair were within the normal limits. With regard to PCBs, the concentration of 2,3,3'4,4',5'-hexachlorobiphenyl in the blood was higher than the maximum reference value.

The two patients with renal carcinoma (patients \#31 and \#32 of Table 1) had higher than normal values of aluminum, antimony, arsenic, cadmium, chromium, mercury, nickel, lead and zinc. In the hair samples, only one patient had arsenic levels twice the normal limit, as well as lead levels about 4 times higher than normal. In both patients, we detected 2,3,4,4',5-pentachlorobiphenyl, 2,3',4,4',5,5'-hexachlorobiphenyl and 2,3,3',4,4',5'-hexachlorobiphenyl.

The patient with peritoneal carcinomatosis from ovarian cancer (patient \#33 of Table 1) had high levels of aluminum, antimony, arsenic, cadmium, chromium, mercury, nickel, lead, copper and zinc. High levels of chromium and lead were found in the hair, as well as the presence of 2,3',4,4',5-pentachlorobiphenyl.

By dividing the patients according to their place of residence, we wanted to highlight the detected levels of chromium, cadmium, arsenic, mercury, and lead in all patients [Tables a-e].

Table 3: References values $(\mu \mathrm{g} / \mathrm{L})$ for metals, proposed for the Italian population in the period 1990-2009 (from Rapporto ISTISAN 10/22) [25]

\begin{tabular}{|c|c|c|}
\hline Metal & $\begin{array}{c}\text { Min blood threshold } \\
\text { value }\end{array}$ & $\begin{array}{c}\text { Max blood threshold } \\
\text { value }\end{array}$ \\
\hline Aluminum & 5.93 & 33.3 \\
\hline Antimony & 0.07 & 0.94 \\
\hline Arsenic & 0.4 & 11.9 \\
\hline Barium & 0.5 & 2.4 \\
\hline Cadmium & 0.25 & 1.97 \\
\hline Chromium & 0.12 & 1.07 \\
\hline Copper & 686 & 1157 \\
\hline Iron & 453519 & 646491 \\
\hline Lead & 12.8 & 79.5 \\
\hline Lithium & 0.2 & 1.87 \\
\hline Mercury & 1.7 & 9.9 \\
\hline Nickel & 0.14 & 2.13 \\
\hline Selenium & 85.4 & 277 \\
\hline Strontium & 0.63 & 2.61 \\
\hline Zinc & 5189 & 8337 \\
\hline
\end{tabular}




\begin{tabular}{|c|c|c|c|c|c|c|}
\hline \multicolumn{7}{|c|}{ Table a } \\
\hline ID & GENDER & AGE & DISEASE & PROVINCE & PLACE OF RESIDENCE & Arsenic \\
\hline 7 & M & 51 & TESTICULAR SEMINOMA & NAPLES & Aversa & 44.9 \\
\hline 20 & M & 26 & $\begin{array}{l}\text { MEDIASTINAL NON-SEMINOMATOUS GERM } \\
\text { CELL TUMOR }\end{array}$ & NAPLES & Frattamaggiore & 42.9 \\
\hline 18 & M & 42 & $\begin{array}{l}\text { TESTICULAR EMBRYONAL CARCINOMA AND } \\
\text { HODGKIN LYMPHOMA }\end{array}$ & NAPLES & Naples & 41.8 \\
\hline 27 & M & 73 & $\begin{array}{c}\text { TONSILLAR NON-HODGKIN MANTLE CELL } \\
\text { LYMPHOMA }\end{array}$ & NAPLES & Frignano & 41.5 \\
\hline 29 & $\mathrm{~F}$ & 47 & PAPILLARY THYROID CARCINOMA & NAPLES & Aversa & 39.7 \\
\hline 7 & $\mathrm{~F}$ & 60 & $\begin{array}{l}\text { DUCTAL BREAST CARCINOMA AND BONE } \\
\text { METASTASIS }\end{array}$ & CASERTA & Sessa Aurunca & 39.7 \\
\hline 32 & $\mathrm{~F}$ & 31 & ONCOCYTOMA - RENAL CARCINOMA & POTENZA & Brienza & 39.6 \\
\hline 14 & $\mathrm{~F}$ & 59 & $\begin{array}{l}\text { GASTRIC CANCER - SIGNET RING CELL } \\
\text { CARCINOMA }\end{array}$ & SALERNO & Salerno & 39.2 \\
\hline 11 & M & 59 & RECTAL AND BLADDER CARCINOMA & NAPLES & Naples & 39.2 \\
\hline 10 & $\mathrm{~F}$ & 50 & MULTIFOCAL BREAST CARCINOMA & POTENZA & Potenza & 39.1 \\
\hline 16 & M & 48 & TESTICULAR SEMINOMA & NAPLES & Giugliano & 38.8 \\
\hline 15 & $\mathrm{~F}$ & 55 & GASTRIC CANCER - ADENOCARCINOMA & POTENZA & Lavello & 38.6 \\
\hline 4 & $\mathrm{~F}$ & 44 & DUCTAL BREAST CARCINOMA & NAPLES & Naples & 38.2 \\
\hline 9 & $\mathrm{~F}$ & 58 & DUCTAL BREAST CARCINOMA & NAPLES & Qualiano & 37.2 \\
\hline 3 & $\mathrm{~F}$ & 33 & DUCTAL BREAST CARCINOMA & POTENZA & Lavello & 37.1 \\
\hline 12 & M & 66 & APPENDIX CARCINOMA & NAPLES & Casoria & 36.7 \\
\hline 23 & M & 31 & HODGKIN LYMPHOMA & NAPLES & Casoria & 35.8 \\
\hline 8 & $\mathrm{~F}$ & 50 & DUCTAL BREAST CARCINOMA & POTENZA & Palazzo San Gervasio & 35.7 \\
\hline 28 & M & 23 & PAPILLARY THYROID CARCINOMA & SALERNO & Cava dei Tirreni & 35.6 \\
\hline 5 & $\mathrm{~F}$ & 50 & $\begin{array}{l}\text { MUCINOUS AND LOBULAR DUCTAL BREAST } \\
\text { CARCINOMA }\end{array}$ & NAPLES & Quarto & 34.3 \\
\hline 24 & $\mathrm{~F}$ & 57 & LARYNGEAL CARCINOMA & NAPLES & Naples & 31.9 \\
\hline 31 & M & 65 & RENAL CARCINOMA & POTENZA & Senise & 31.8 \\
\hline 2 & $\mathrm{~F}$ & 50 & DUCTAL BREAST CARCINOMA & NAPLES & Qualiano & 31.6 \\
\hline 25 & M & 70 & LARYNGEAL CARCINOMA & NAPLES & Naples & 31.2 \\
\hline 19 & M & 39 & $\begin{array}{c}\text { RECTAL CANCER - PAPILLARY CANCER - } \\
\text { HODGKIN LYMPHOMA }\end{array}$ & NAPLES & Acerra & 31.2 \\
\hline 21 & $\mathrm{~F}$ & 6 & LYMPHOBLASTIC LEUKEMIA & NAPLES & Giugliano & 30.1 \\
\hline 22 & $\mathrm{~F}$ & 54 & MYELOID LEUKEMIA & POTENZA & Potenza & 28.6 \\
\hline 33 & $\mathrm{~F}$ & 65 & $\begin{array}{l}\text { OVARIAN CANCER AND PERITONEAL } \\
\text { METASTASIS }\end{array}$ & POTENZA & Orta di Atella & 25.9 \\
\hline 30 & $\mathrm{~F}$ & 65 & FOLLICULAR THYROID CARCINOMA & NAPLES & Casalnuovo & 16.5 \\
\hline 6 & $\mathrm{~F}$ & 60 & $\begin{array}{l}\text { DUCTAL BREAST CARCINOMA AND HODGKIN } \\
\text { LYMPHOMA }\end{array}$ & NAPLES & Villaricca & 16.5 \\
\hline 1 & $\mathrm{~F}$ & 47 & DUCTAL BREAST CARCINOMA & NAPLES & Giugliano & 15.1 \\
\hline 13 & M & 63 & GASTRIC CANCER - ADENOCARCINOMA & CASERTA & Casapenna & 10.4 \\
\hline 26 & $\mathrm{~F}$ & 46 & NASOPHARYNGEAL CARCINOMA & NAPLES & Naples & 9.69 \\
\hline
\end{tabular}




\begin{tabular}{|c|c|c|c|c|c|c|}
\hline \multicolumn{7}{|c|}{ Table b } \\
\hline ID & GENDER & AGE & DISEASE & PROVINCE & PLACE OF RESIDENCE & Cadmium \\
\hline 5 & $\mathrm{~F}$ & 50 & $\begin{array}{l}\text { MUCINOUS AND LOBULAR DUCTAL BREAST } \\
\text { CARCINOMA }\end{array}$ & NAPLES & Quarto & 13.9 \\
\hline 17 & M & 51 & TESTICULAR SEMINOMA & NAPLES & Aversa & 13.5 \\
\hline 29 & $\mathrm{~F}$ & 47 & PAPILLARY THYROID CARCINOMA & NAPLES & Aversa & 12.6 \\
\hline 20 & M & 26 & $\begin{array}{l}\text { MEDIASTINAL NON-SEMINOMATOUS GERM } \\
\text { CELL TUMOR }\end{array}$ & NAPLES & Frattamaggiore & 12.6 \\
\hline 7 & $\mathrm{~F}$ & 60 & $\begin{array}{l}\text { DUCTAL BREAST CARCINOMA AND BONE } \\
\text { METASTASIS }\end{array}$ & CASERTA & Sessa Aurunca & 12.6 \\
\hline 27 & M & 73 & $\begin{array}{l}\text { TONSILLAR NON-HODGKIN MANTLE CELL } \\
\text { LYMPHOMA }\end{array}$ & NAPLES & Frignano & 12.4 \\
\hline 2 & $\mathrm{~F}$ & 50 & DUCTAL BREAST CARCINOMA & NAPLES & Qualiano & 11.9 \\
\hline 18 & M & 42 & $\begin{array}{l}\text { TESTICULAR EMBRYONAL CARCINOMA AND } \\
\text { HODGKIN LYMPHOMA }\end{array}$ & NAPLES & Naples & 11.8 \\
\hline 11 & M & 59 & RECTAL AND BLADDER CARCINOMA & NAPLES & Naples & 11.5 \\
\hline 4 & $\mathrm{~F}$ & 44 & DUCTAL BREAST CARCINOMA & NAPLES & Naples & 11.5 \\
\hline 16 & M & 48 & TESTICULAR SEMINOMA & NAPLES & Giugliano & 11.3 \\
\hline 10 & $\mathrm{~F}$ & 50 & MULTIFOCAL BREAST CARCINOMA & POTENZA & Potenza & 11.1 \\
\hline 14 & $\mathrm{~F}$ & 59 & $\begin{array}{l}\text { GASTRIC CANCER - SIGNET RING CELL } \\
\text { CARCINOMA }\end{array}$ & SALERNO & Salerno & 10.9 \\
\hline 31 & M & 65 & RENAL CARCINOMA & POTENZA & Senise & 10.7 \\
\hline 9 & $\mathrm{~F}$ & 58 & DUCTAL BREAST CARCINOMA & NAPLES & Qualiano & 10.5 \\
\hline 15 & $\mathrm{~F}$ & 55 & GASTRIC CANCER - ADENOCARCINOMA & POTENZA & Lavello & 10.4 \\
\hline 3 & $\mathrm{~F}$ & 33 & DUCTAL BREAST CARCINOMA & POTENZA & Lavello & 10.4 \\
\hline 24 & $\mathrm{~F}$ & 57 & LARYNGEAL CARCINOMA & NAPLES & Naples & 9.34 \\
\hline 21 & $\mathrm{~F}$ & 6 & LYMPHOBLASTIC LEUKEMIA & NAPLES & Giugliano & 9.31 \\
\hline 19 & M & 39 & $\begin{array}{c}\text { RECTAL CANCER - PAPILLARY CANCER - } \\
\text { HODGKIN LYMPHOMA }\end{array}$ & NAPLES & Acerra & 9.25 \\
\hline 25 & M & 70 & LARYNGEAL CARCINOMA & NAPLES & Naples & 9.24 \\
\hline 32 & $\mathrm{~F}$ & 31 & ONCOCYTOMA - RENAL CARCINOMA & POTENZA & Brienza & 9.22 \\
\hline 8 & $\mathrm{~F}$ & 50 & DUCTAL BREAST CARCINOMA & POTENZA & Palazzo San Gervasio & 9.21 \\
\hline 12 & M & 66 & APPENDIX CARCINOMA & NAPLES & Casoria & 8.64 \\
\hline 28 & M & 23 & PAPILLARY THYROID CARCINOMA & SALERNO & Cava dei Tirreni & 8.38 \\
\hline 23 & M & 31 & HODGKIN LYMPHOMA & NAPLES & Casoria & 8.36 \\
\hline 22 & $\mathrm{~F}$ & 54 & MYELOID LEUKEMIA & POTENZA & Potenza & 7.63 \\
\hline 33 & $\mathrm{~F}$ & 65 & $\begin{array}{l}\text { OVARIAN CANCER AND PERITONEAL } \\
\text { METASTASIS }\end{array}$ & POTENZA & Orta di Atella & 7.21 \\
\hline 1 & $\mathrm{~F}$ & 47 & DUCTAL BREAST CARCINOMA & NAPLES & Giugliano & 2.72 \\
\hline 30 & $\mathrm{~F}$ & 65 & FOLLICULAR THYROID CARCINOMA & NAPLES & Casalnuovo & 2.65 \\
\hline 6 & $\mathrm{~F}$ & 60 & $\begin{array}{l}\text { DUCTAL BREAST CARCINOMA AND HODGKIN } \\
\text { LYMPHOMA }\end{array}$ & NAPLES & Villaricca & 2.65 \\
\hline 26 & $\mathrm{~F}$ & 46 & NASOPHARYNGEAL CARCINOMA & NAPLES & Naples & 2.11 \\
\hline 13 & M & 63 & GASTRIC CANCER - ADENOCARCINOMA & CASERTA & Casapenna & 1.18 \\
\hline
\end{tabular}




\begin{tabular}{|c|c|c|c|c|c|c|}
\hline \multicolumn{7}{|c|}{ Table c } \\
\hline ID & GENDER & AGE & DISEASE & PROVINCE & PLACE OF RESIDENCE & Chromium \\
\hline 2 & $\mathrm{~F}$ & 50 & DUCTAL BREAST CARCINOMA & NAPLES & Qualiano & 4.37 \\
\hline 5 & $\mathrm{~F}$ & 50 & $\begin{array}{l}\text { MUCINOUS AND LOBULAR DUCTAL BREAST } \\
\text { CARCINOMA }\end{array}$ & NAPLES & Quarto & 4.28 \\
\hline 9 & $\mathrm{~F}$ & 58 & DUCTAL BREAST CARCINOMA & NAPLES & Qualiano & 4.14 \\
\hline 3 & $\mathrm{~F}$ & 33 & DUCTAL BREAST CARCINOMA & POTENZA & Lavello & 4.11 \\
\hline 18 & M & 42 & $\begin{array}{c}\text { TESTICULAR EMBRYONAL CARCINOMA AND } \\
\text { HODGKIN LYMPHOMA }\end{array}$ & NAPLES & Naples & 4.01 \\
\hline 27 & M & 73 & $\begin{array}{c}\text { TONSILLAR NON-HODGKIN MANTLE CELL } \\
\text { LYMPHOMA }\end{array}$ & NAPLES & Frignano & 4.01 \\
\hline 14 & $\mathrm{~F}$ & 59 & $\begin{array}{l}\text { GASTRIC CANCER - SIGNET RING CELL } \\
\text { CARCINOMA }\end{array}$ & SALERNO & Salerno & 3.98 \\
\hline 20 & M & 26 & $\begin{array}{l}\text { MEDIASTINAL NON-SEMINOMATOUS GERM } \\
\text { CELL TUMOR }\end{array}$ & NAPLES & Frattamaggiore & 3.92 \\
\hline 10 & $\mathrm{~F}$ & 50 & MULTIFOCAL BREAST CARCINOMA & POTENZA & Potenza & 3.86 \\
\hline 28 & M & 23 & PAPILLARY THYROID CARCINOMA & SALERNO & Cava dei Tirreni & 3.86 \\
\hline 7 & $\mathrm{~F}$ & 60 & $\begin{array}{l}\text { DUCTAL BREAST CARCINOMA AND BONE } \\
\text { METASTASIS }\end{array}$ & CASERTA & Sessa Aurunca & 3.77 \\
\hline 29 & $\mathrm{~F}$ & 47 & PAPILLARY THYROID CARCINOMA & NAPLES & Aversa & 3.77 \\
\hline 23 & M & 31 & HODGKIN LYMPHOMA & NAPLES & Casoria & 3.76 \\
\hline 8 & $\mathrm{~F}$ & 50 & DUCTAL BREAST CARCINOMA & POTENZA & Palazzo San Gervasio & 3.62 \\
\hline 15 & $\mathrm{~F}$ & 55 & GASTRIC CANCER - ADENOCARCINOMA & POTENZA & Lavello & 3.46 \\
\hline 24 & $\mathrm{~F}$ & 57 & LARYNGEAL CARCINOMA & NAPLES & Naples & 3.26 \\
\hline 12 & M & 66 & APPENDIX CARCINOMA & NAPLES & Casoria & 3.25 \\
\hline 21 & $\mathrm{~F}$ & 6 & LYMPHOBLASTIC LEUKEMIA & NAPLES & Giugliano & 3.23 \\
\hline 25 & M & 70 & LARYNGEAL CARCINOMA & NAPLES & Naples & 3.16 \\
\hline 19 & M & 39 & $\begin{array}{c}\text { RECTAL CANCER - PAPILLARY CANCER - } \\
\text { HODGKIN LYMPHOMA }\end{array}$ & NAPLES & Acerra & 3.12 \\
\hline 11 & M & 59 & RECTAL AND BLADDER CARCINOMA & NAPLES & Naples & 2.99 \\
\hline 4 & $\mathrm{~F}$ & 44 & DUCTAL BREAST CARCINOMA & NAPLES & Naples & 2.98 \\
\hline 16 & M & 48 & TESTICULAR SEMINOMA & NAPLES & Giugliano & 2.93 \\
\hline 32 & $\mathrm{~F}$ & 31 & ONCOCYTOMA - RENAL CARCINOMA & POTENZA & Brienza & 2.93 \\
\hline 33 & $\mathrm{~F}$ & 65 & $\begin{array}{l}\text { OVARIAN CANCER AND PERITONEAL } \\
\text { METASTASIS }\end{array}$ & POTENZA & Orta di Atella & 2.93 \\
\hline 22 & $\mathrm{~F}$ & 54 & MYELOID LEUKEMIA & POTENZA & Potenza & 2.91 \\
\hline 17 & $\mathrm{M}$ & 51 & TESTICULAR SEMINOMA & NAPLES & Aversa & 2.88 \\
\hline 31 & M & 65 & RENAL CARCINOMA & POTENZA & Senise & 2.83 \\
\hline 6 & $\mathrm{~F}$ & 60 & $\begin{array}{l}\text { DUCTAL BREAST CARCINOMA AND HODGKIN } \\
\text { LYMPHOMA }\end{array}$ & NAPLES & Villaricca & 0.46 \\
\hline 30 & $\mathrm{~F}$ & 65 & FOLLICULAR THYROID CARCINOMA & NAPLES & Casalnuovo & 0.46 \\
\hline 1 & $\mathrm{~F}$ & 47 & DUCTAL BREAST CARCINOMA & NAPLES & Giugliano & 0.31 \\
\hline 26 & $\mathrm{~F}$ & 46 & NASOPHARYNGEAL CARCINOMA & NAPLES & Naples & 0.31 \\
\hline 13 & M & 63 & GASTRIC CANCER - ADENOCARCINOMA & CASERTA & Casapenna & 0.15 \\
\hline
\end{tabular}




\begin{tabular}{|c|c|c|c|c|c|c|}
\hline \multicolumn{7}{|c|}{ Table d } \\
\hline ID & GENDER & AGE & DISEASE & PROVINCE & PLACE OF RESIDENCE & Mercury \\
\hline 17 & M & 51 & TESTICULAR SEMINOMA & NAPLES & Aversa & 46.7 \\
\hline 23 & M & 31 & HODGKIN LYMPHOMA & NAPLES & Casoria & 39.6 \\
\hline 28 & M & 23 & PAPILLARY THYROID CARCINOMA & SALERNO & Cava dei Tirreni & 39.2 \\
\hline 5 & $\mathrm{~F}$ & 50 & $\begin{array}{l}\text { MUCINOUS AND LOBULAR DUCTAL BREAST } \\
\text { CARCINOMA }\end{array}$ & NAPLES & Quarto & 38.6 \\
\hline 3 & $\mathrm{~F}$ & 33 & DUCTAL BREAST CARCINOMA & POTENZA & Lavello & 36.9 \\
\hline 9 & $\mathrm{~F}$ & 58 & DUCTAL BREAST CARCINOMA & NAPLES & Qualiano & 36.7 \\
\hline 20 & M & 26 & $\begin{array}{l}\text { MEDIASTINAL NON-SEMINOMATOUS GERM CELL } \\
\text { TUMOR }\end{array}$ & NAPLES & Frattamaggiore & 36.5 \\
\hline 27 & M & 73 & $\begin{array}{l}\text { TONSILLAR NON-HODGKIN MANTLE CELL } \\
\text { LYMPHOMA }\end{array}$ & NAPLES & Frignano & 36.4 \\
\hline 18 & M & 42 & $\begin{array}{c}\text { TESTICULAR EMBRYONAL CARCINOMA AND } \\
\text { HODGKIN LYMPHOMA }\end{array}$ & NAPLES & Naples & 35.8 \\
\hline 14 & $\mathrm{~F}$ & 59 & $\begin{array}{c}\text { GASTRIC CANCER - SIGNET RING CELL } \\
\text { CARCINOMA }\end{array}$ & SALERNO & Salerno & 34.9 \\
\hline 10 & $\mathrm{~F}$ & 50 & MULTIFOCAL BREAST CARCINOMA & POTENZA & Potenza & 34.6 \\
\hline 2 & $\mathrm{~F}$ & 50 & DUCTAL BREAST CARCINOMA & NAPLES & Qualiano & 34.2 \\
\hline 11 & M & 59 & RECTAL AND BLADDER CARCINOMA & NAPLES & Naples & 32.8 \\
\hline 8 & $\mathrm{~F}$ & 50 & DUCTAL BREAST CARCINOMA & POTENZA & Palazzo San Gervasio & 31.6 \\
\hline 16 & M & 48 & TESTICULAR SEMINOMA & NAPLES & Giugliano & 31.5 \\
\hline 7 & $\mathrm{~F}$ & 60 & $\begin{array}{l}\text { DUCTAL BREAST CARCINOMA AND BONE } \\
\text { METASTASIS }\end{array}$ & CASERTA & Sessa Aurunca & 31.4 \\
\hline 29 & $\mathrm{~F}$ & 47 & PAPILLARY THYROID CARCINOMA & NAPLES & Aversa & 31.4 \\
\hline 4 & $\mathrm{~F}$ & 44 & DUCTAL BREAST CARCINOMA & NAPLES & Naples & 31.3 \\
\hline 32 & $\mathrm{~F}$ & 31 & ONCOCYTOMA - RENAL CARCINOMA & POTENZA & Brienza & 30.8 \\
\hline 21 & $\mathrm{~F}$ & 6 & LYMPHOBLASTIC LEUKEMIA & NAPLES & Giugliano & 30.6 \\
\hline 12 & M & 66 & APPENDIX CARCINOMA & NAPLES & Casoria & 29.5 \\
\hline 31 & M & 65 & RENAL CARCINOMA & POTENZA & Senise & 28.6 \\
\hline 19 & M & 39 & $\begin{array}{c}\text { RECTAL CANCER - PAPILLARY CANCER - } \\
\text { HODGKIN LYMPHOMA }\end{array}$ & NAPLES & Acerra & 28.3 \\
\hline 24 & $\mathrm{~F}$ & 57 & LARYNGEAL CARCINOMA & NAPLES & Naples & 28.2 \\
\hline 25 & M & 70 & LARYNGEAL CARCINOMA & NAPLES & Naples & 28.1 \\
\hline 15 & $\mathrm{~F}$ & 55 & GASTRIC CANCER - ADENOCARCINOMA & POTENZA & Lavello & 25.7 \\
\hline 33 & $\mathrm{~F}$ & 65 & $\begin{array}{l}\text { OVARIAN CANCER AND PERITONEAL } \\
\text { METASTASIS }\end{array}$ & POTENZA & Orta di Atella & 22.4 \\
\hline 22 & $\mathrm{~F}$ & 54 & MYELOID LEUKEMIA & POTENZA & Potenza & 19.6 \\
\hline 1 & $\mathrm{~F}$ & 47 & DUCTAL BREAST CARCINOMA & NAPLES & Giugliano & 14.3 \\
\hline 6 & $\mathrm{~F}$ & 60 & $\begin{array}{l}\text { DUCTAL BREAST CARCINOMA AND HODGKIN } \\
\text { LYMPHOMA }\end{array}$ & NAPLES & Villaricca & 12.2 \\
\hline 30 & $\mathrm{~F}$ & 65 & FOLLICULAR THYROID CARCINOMA & NAPLES & Casalnuovo & 12.2 \\
\hline 26 & $\mathrm{~F}$ & 46 & NASOPHARYNGEAL CARCINOMA & NAPLES & Naples & 8.6 \\
\hline 13 & M & 63 & GASTRIC CANCER - ADENOCARCINOMA & CASERTA & Casapenna & 8.22 \\
\hline
\end{tabular}




\begin{tabular}{|c|c|c|c|c|c|c|}
\hline \multicolumn{7}{|l|}{ Table e } \\
\hline ID & GENDER & AGE & DISEASE & PROVINCE & PLACE OF RESIDENCE & Lead \\
\hline 17 & M & 51 & TESTICULAR SEMINOMA & NAPLES & Aversa & 337 \\
\hline 12 & M & 66 & APPENDIX CARCINOMA & NAPLES & Casoria & 321 \\
\hline 20 & M & 26 & $\begin{array}{l}\text { MEDIASTINAL NON-SEMINOMATOUS GERM } \\
\text { CELL TUMOR }\end{array}$ & NAPLES & Frattamaggiore & 307 \\
\hline 3 & $\mathrm{~F}$ & 33 & DUCTAL BREAST CARCINOMA & POTENZA & Lavello & 306 \\
\hline 9 & $\mathrm{~F}$ & 58 & DUCTAL BREAST CARCINOMA & NAPLES & Qualiano & 302 \\
\hline 10 & $\mathrm{~F}$ & 50 & MULTIFOCAL BREAST CARCINOMA & POTENZA & Potenza & 298 \\
\hline 14 & $\mathrm{~F}$ & 59 & $\begin{array}{l}\text { GASTRIC CANCER - SIGNET RING CELL } \\
\text { CARCINOMA }\end{array}$ & SALERNO & Salerno & 298 \\
\hline 23 & M & 31 & HODGKIN LYMPHOMA & NAPLES & Casoria & 288 \\
\hline 18 & M & 42 & $\begin{array}{c}\text { TESTICULAR EMBRYONAL CARCINOMA AND } \\
\text { HODGKIN LYMPHOMA }\end{array}$ & NAPLES & Naples & 284 \\
\hline 28 & M & 23 & PAPILLARY THYROID CARCINOMA & SALERNO & Cava dei Tirreni & 283 \\
\hline 4 & $\mathrm{~F}$ & 44 & DUCTAL BREAST CARCINOMA & NAPLES & Naples & 272 \\
\hline 16 & M & 48 & TESTICULAR SEMINOMA & NAPLES & Giugliano & 269 \\
\hline 31 & M & 65 & RENAL CARCINOMA & POTENZA & Senise & 267 \\
\hline 11 & M & 59 & RECTAL AND BLADDER CARCINOMA & NAPLES & Naples & 262 \\
\hline 5 & $\mathrm{~F}$ & 50 & $\begin{array}{l}\text { MUCINOUS AND LOBULAR DUCTAL BREAST } \\
\text { CARCINOMA }\end{array}$ & NAPLES & Quarto & 252 \\
\hline 8 & $\mathrm{~F}$ & 50 & DUCTAL BREAST CARCINOMA & POTENZA & Palazzo San Gervasio & 252 \\
\hline 32 & $\mathrm{~F}$ & 31 & ONCOCYTOMA - RENAL CARCINOMA & POTENZA & Brienza & 249 \\
\hline 7 & $\mathrm{~F}$ & 60 & $\begin{array}{l}\text { DUCTAL BREAST CARCINOMA AND BONE } \\
\text { METASTASIS }\end{array}$ & CASERTA & Sessa Aurunca & 243 \\
\hline 29 & $\mathrm{~F}$ & 47 & PAPILLARY THYROID CARCINOMA & NAPLES & Aversa & 243 \\
\hline 27 & M & 73 & $\begin{array}{c}\text { TONSILLAR NON-HODGKIN MANTLE CELL } \\
\text { LYMPHOMA }\end{array}$ & NAPLES & Frignano & 225 \\
\hline 21 & $\mathrm{~F}$ & 6 & LYMPHOBLASTIC LEUKEMIA & NAPLES & Giugliano & 219 \\
\hline 19 & M & 39 & $\begin{array}{c}\text { RECTAL CANCER - PAPILLARY CANCER - } \\
\text { HODGKIN LYMPHOMA }\end{array}$ & NAPLES & Acerra & 215 \\
\hline 24 & $\mathrm{~F}$ & 57 & LARYNGEAL CARCINOMA & NAPLES & Naples & 213 \\
\hline 25 & M & 70 & LARYNGEAL CARCINOMA & NAPLES & Naples & 213 \\
\hline 2 & $\mathrm{~F}$ & 50 & DUCTAL BREAST CARCINOMA & NAPLES & Qualiano & 196 \\
\hline 15 & $\mathrm{~F}$ & 55 & GASTRIC CANCER - ADENOCARCINOMA & POTENZA & Lavello & 193 \\
\hline 22 & $\mathrm{~F}$ & 54 & MYELOID LEUKEMIA & POTENZA & Potenza & 113 \\
\hline 26 & $\mathrm{~F}$ & 46 & NASOPHARYNGEAL CARCINOMA & NAPLES & Naples & 110 \\
\hline 33 & $\mathrm{~F}$ & 65 & $\begin{array}{l}\text { OVARIAN CANCER AND PERITONEAL } \\
\text { METASTASIS }\end{array}$ & POTENZA & Orta di Atella & 110 \\
\hline 1 & $\mathrm{~F}$ & 47 & DUCTAL BREAST CARCINOMA & NAPLES & Giugliano & 94.1 \\
\hline 6 & $\mathrm{~F}$ & 60 & $\begin{array}{l}\text { DUCTAL BREAST CARCINOMA AND } \\
\text { HODGKIN LYMPHOMA }\end{array}$ & NAPLES & Villaricca & 92.4 \\
\hline 30 & $\mathrm{~F}$ & 65 & FOLLICULAR THYROID CARCINOMA & NAPLES & Casalnuovo & 92.4 \\
\hline 13 & M & 63 & GASTRIC CANCER - ADENOCARCINOMA & CASERTA & Casapenna & 80.7 \\
\hline
\end{tabular}


The figures (1-14) graphically display the levels of 14 metals based on provincial towns.

The highest levels of metals were found in the patient with testicular seminoma from Aversa. High levels of metals were also found in all ductal carcinomas of the breast. Overall, heavy metal levels were significantly higher (at least 3 times the maximum allowed by the reference tables) in different combinations depending on the geographical area and the type of cancer. With small exceptions, we were able to detect the same metals, and even the same PCBs, in patients with certain types of cancer, such as breast cancer. We found no correlation between the stage and severity of cancer and the levels of metals. We believe that a largescale study would be appropriate, with the aim of obtaining as much data as possible, in view of the fact that the intimate relationship between the presence of these substances and oncogenesis is currently still unclear. However, we believe that - also in the light of the results obtained by other research groups [1-3, 16] - there is a common denominator that forces us to pay close attention to everything we put into the environment we live in, and to clean-up anything containing high levels of these substances.

\section{Zinc}

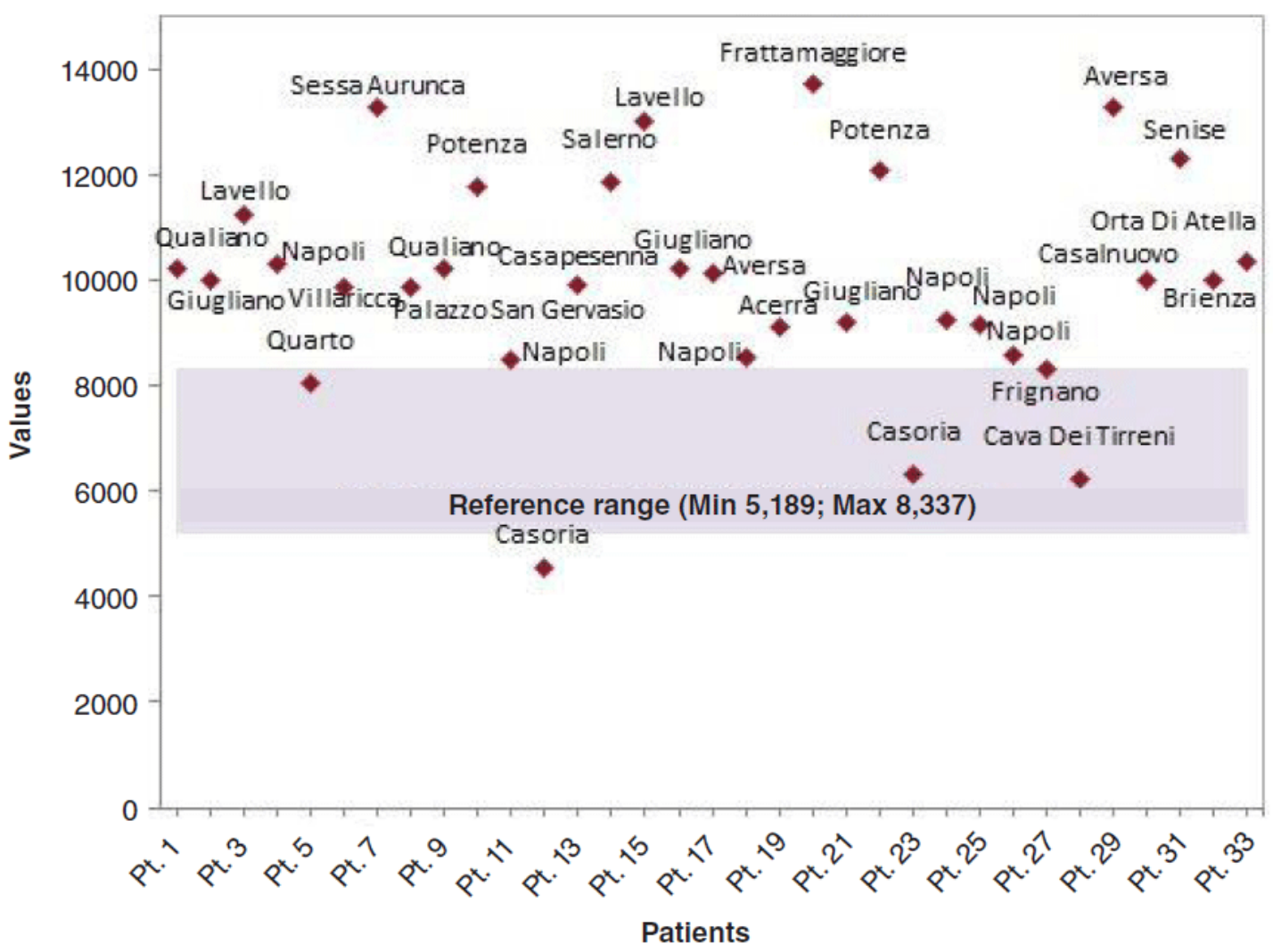

Figure 1: 


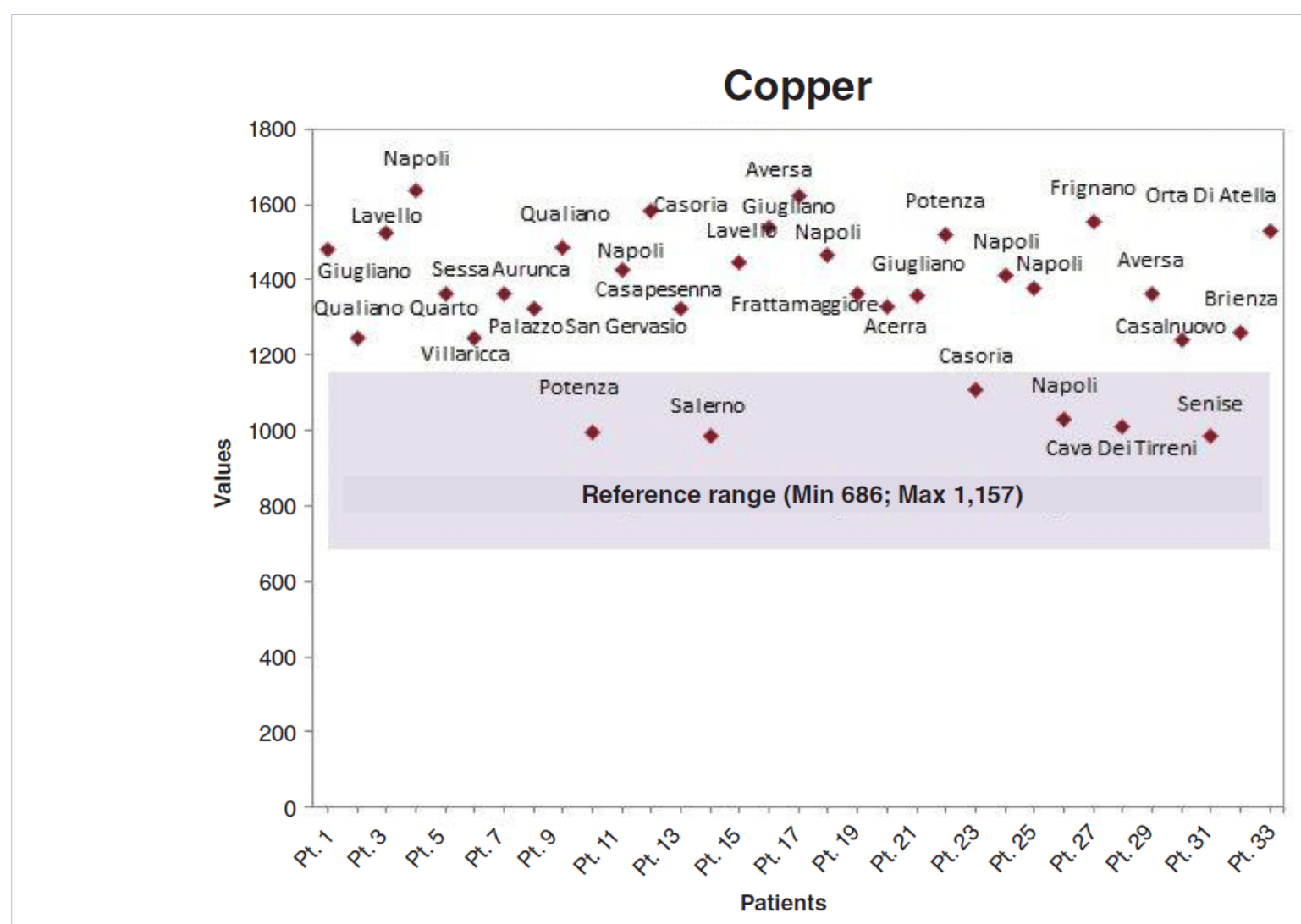

Figure 2:

\section{Lead}

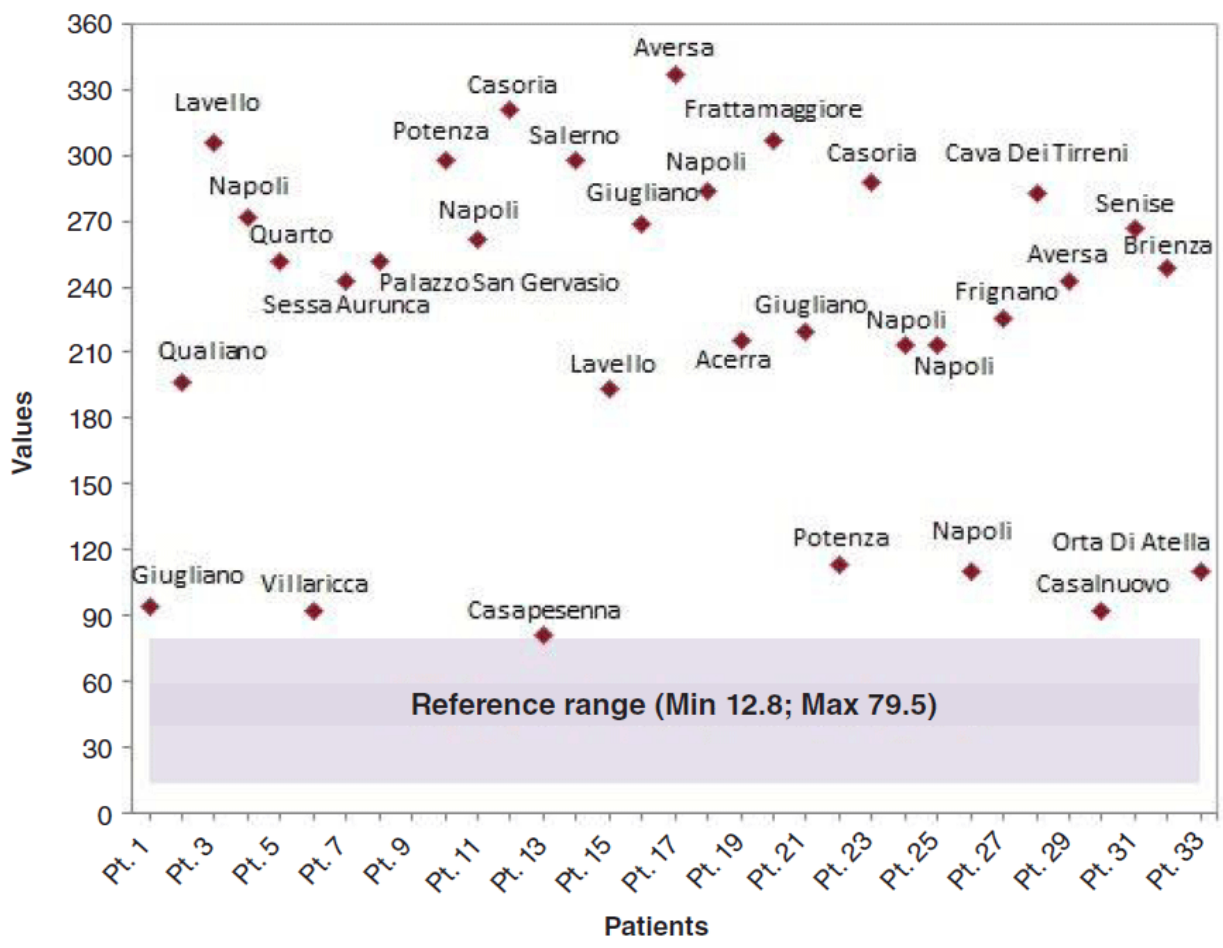

Figure 3:

Citation: Petrosino V, Coletta M, Testa D (2019) Determination of Heavy Metals and Polychlorinated Biphenyls in Oncological

Patients: A Pilot Study. Cancer Sci Res Open Access 6(1): 1-20. DOI: 10.15226/csroa.2019.00152 


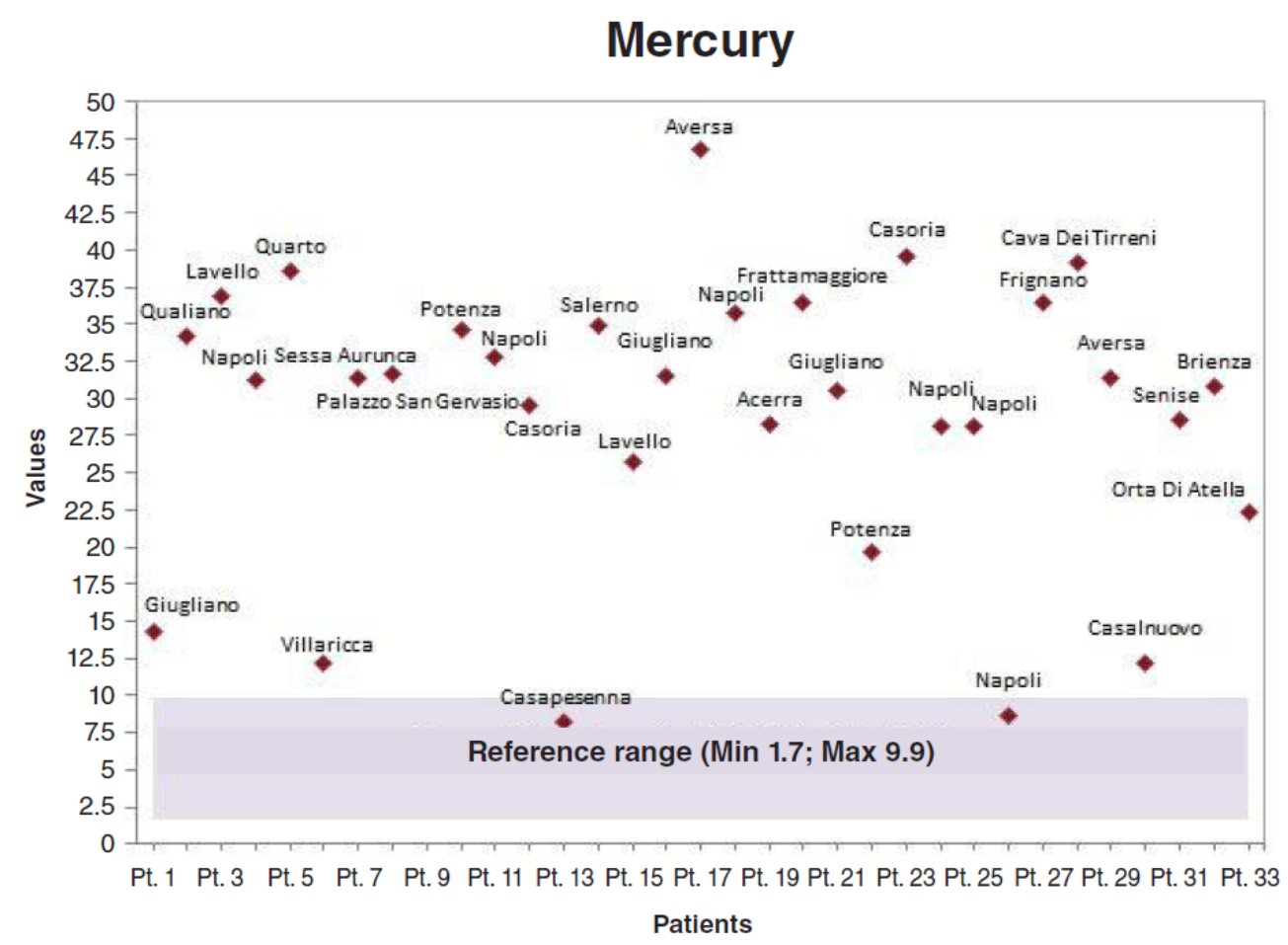

Figure 4:

\section{Chromium}

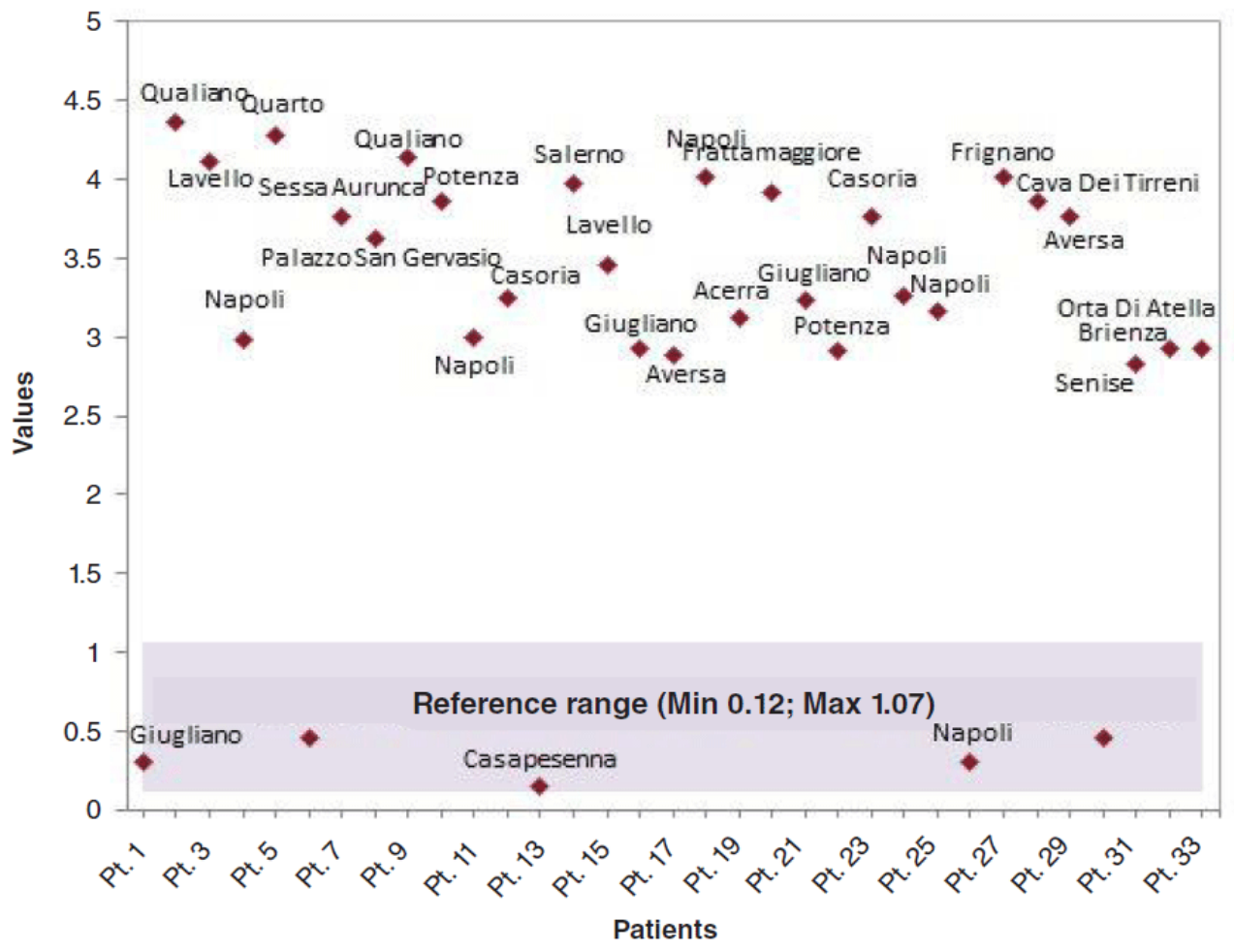

Figure 5: 


\section{Cadmium}

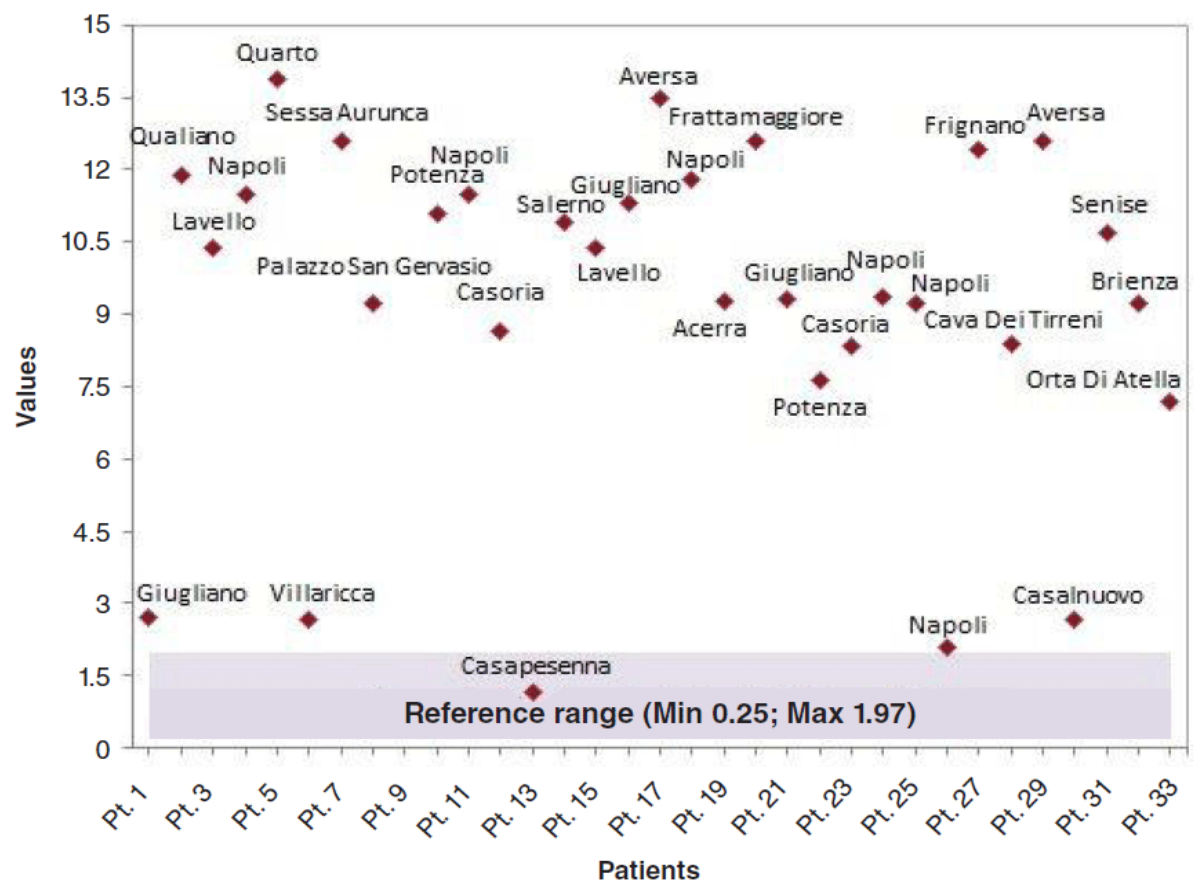

Figure 6:

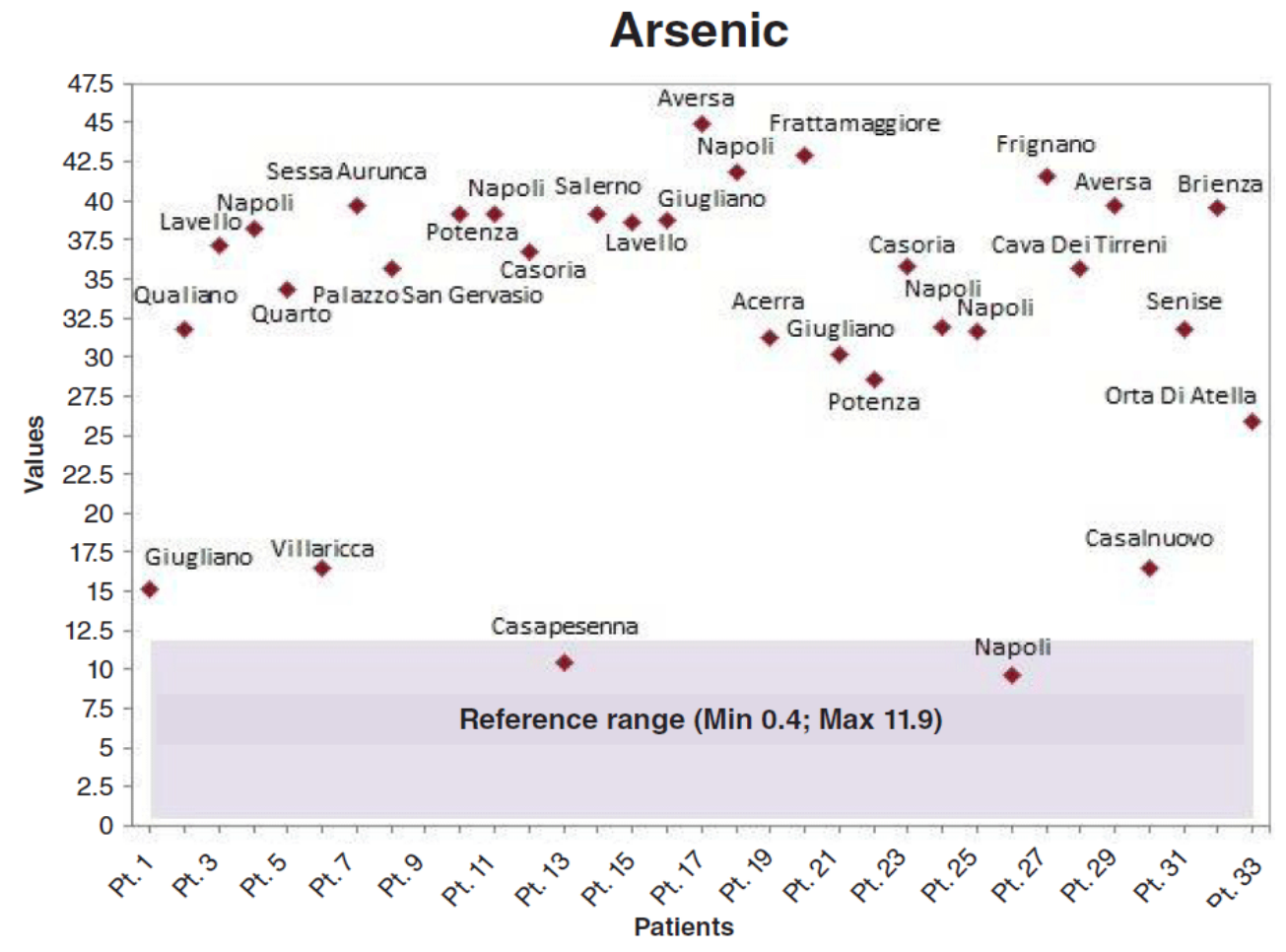

Figure 7: 


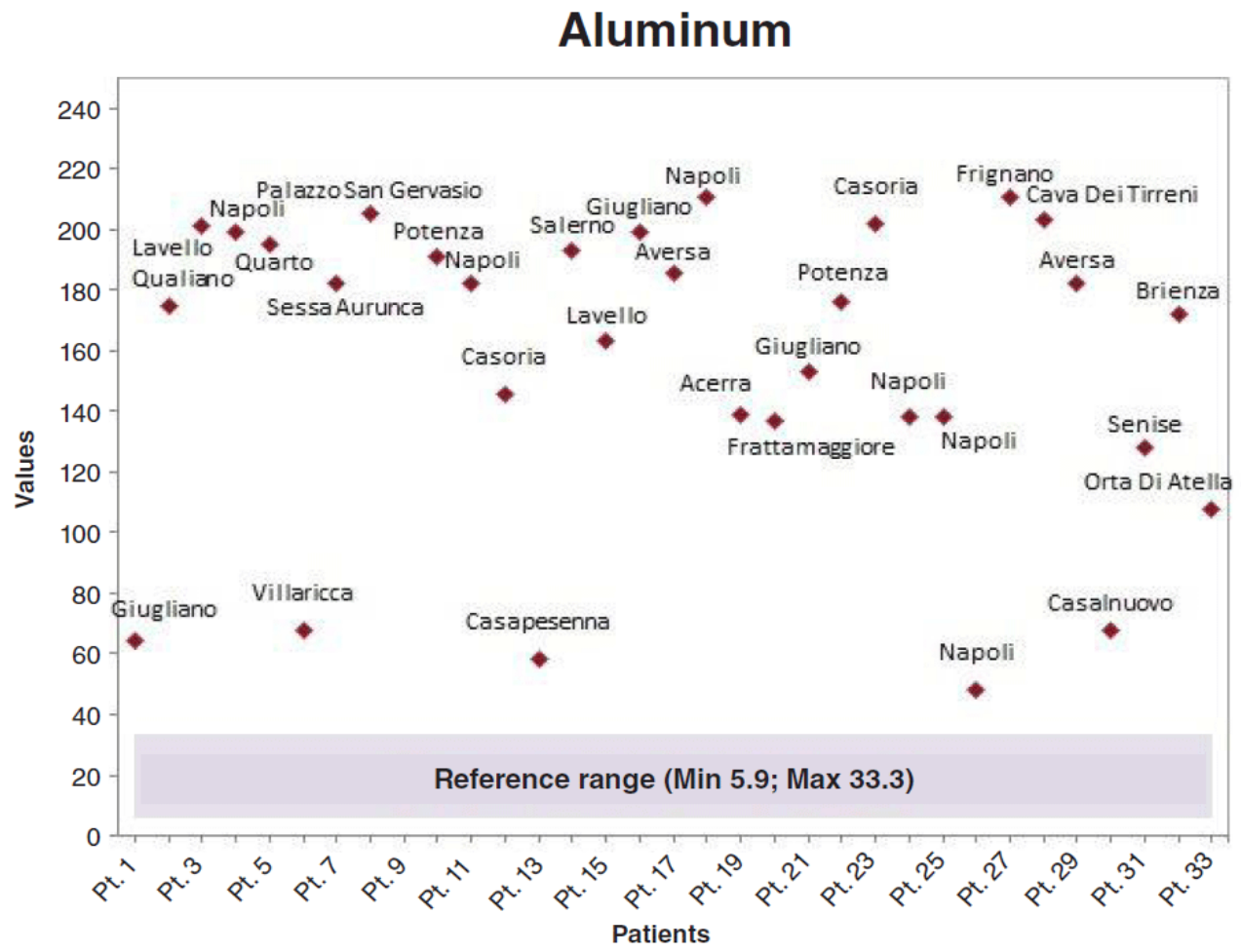

Figure 8:

\section{Nickel}

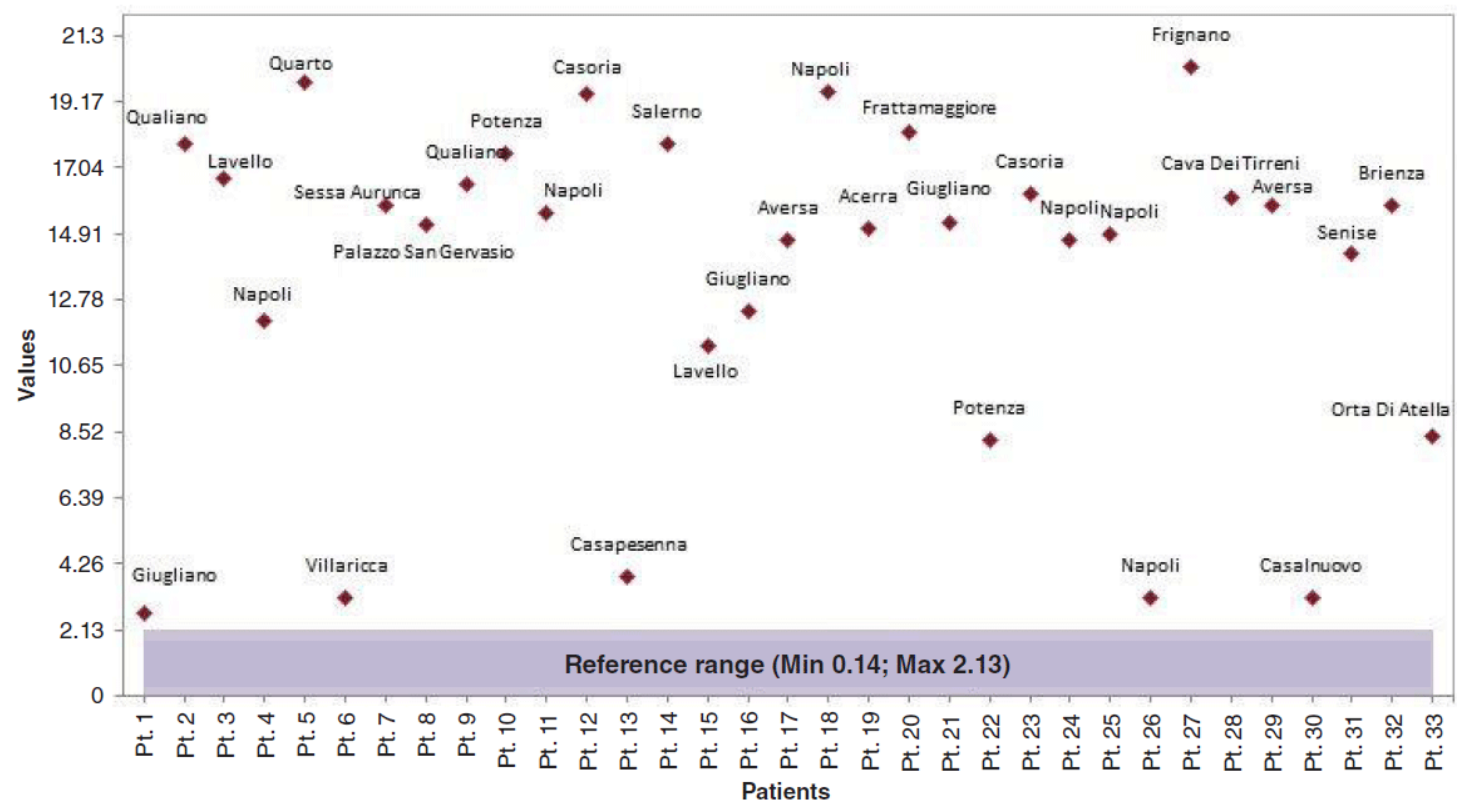

Figure 9: 


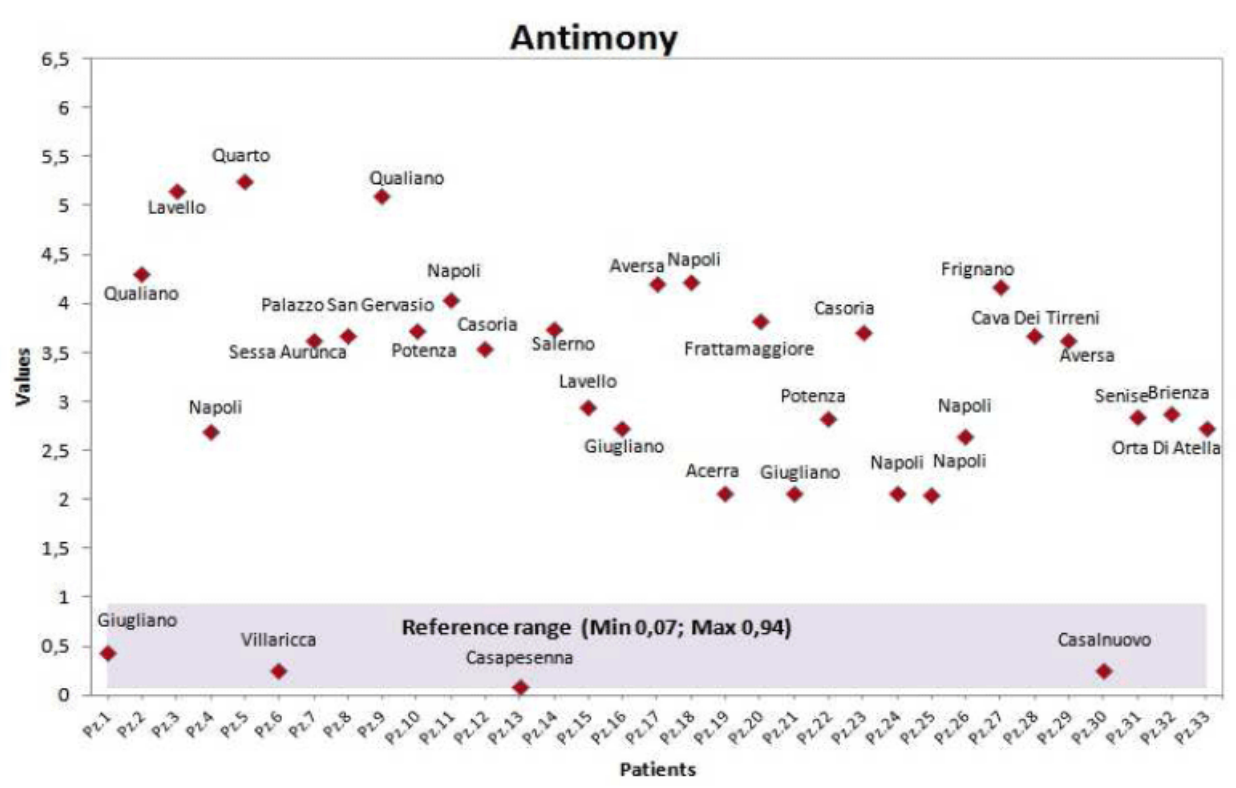

Figure 10:

\section{Barium}

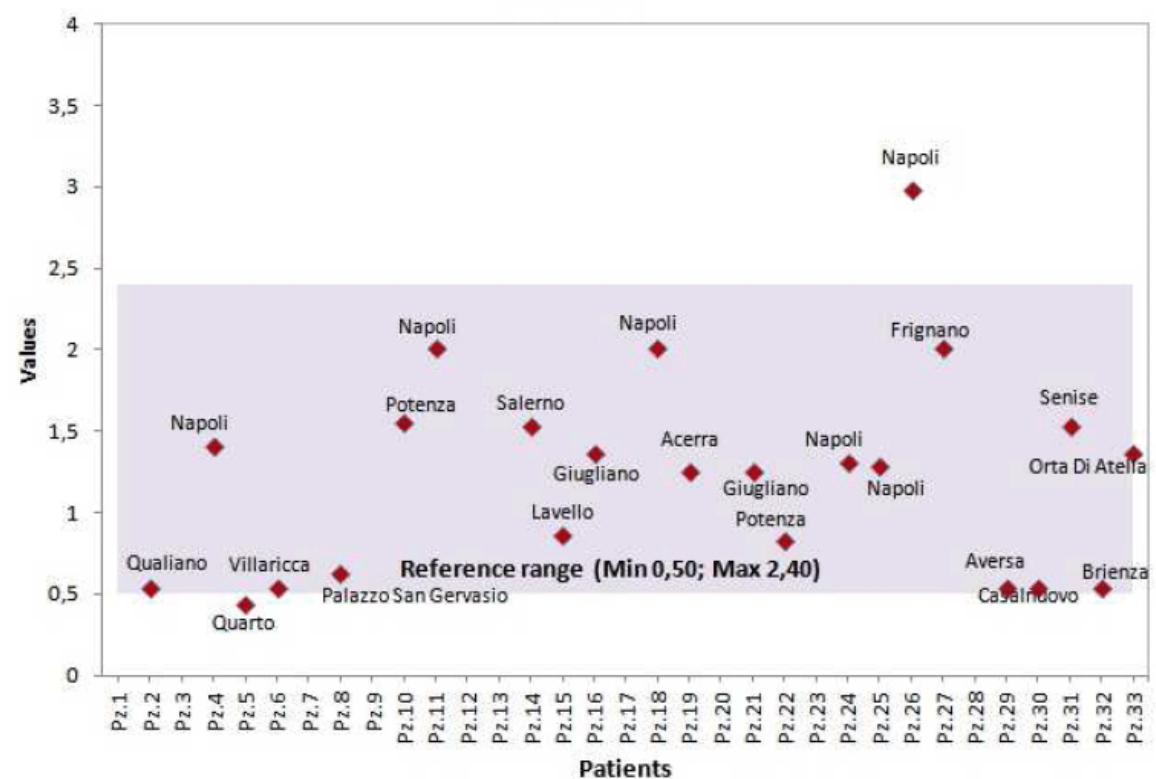

Figure 11: 


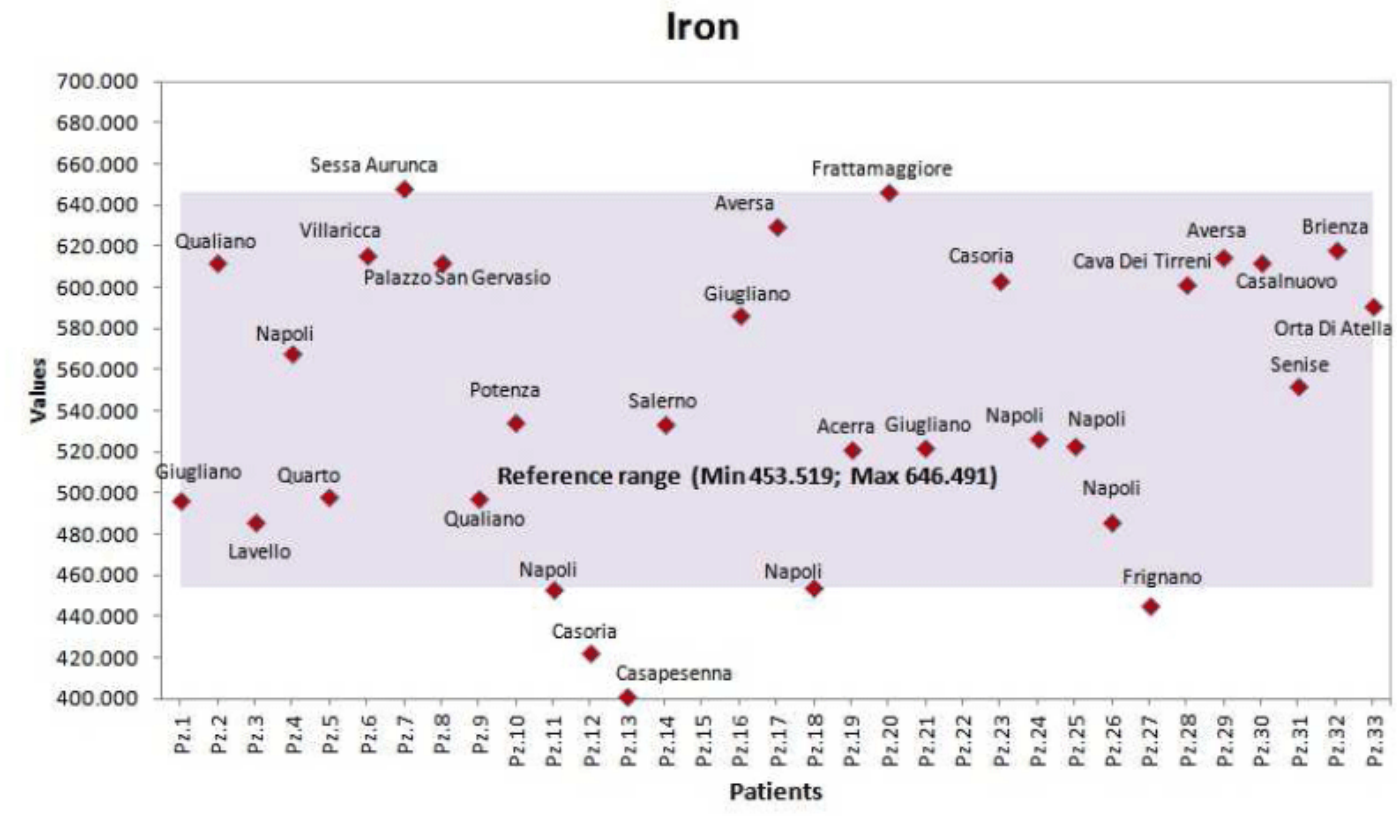

Figure 12:

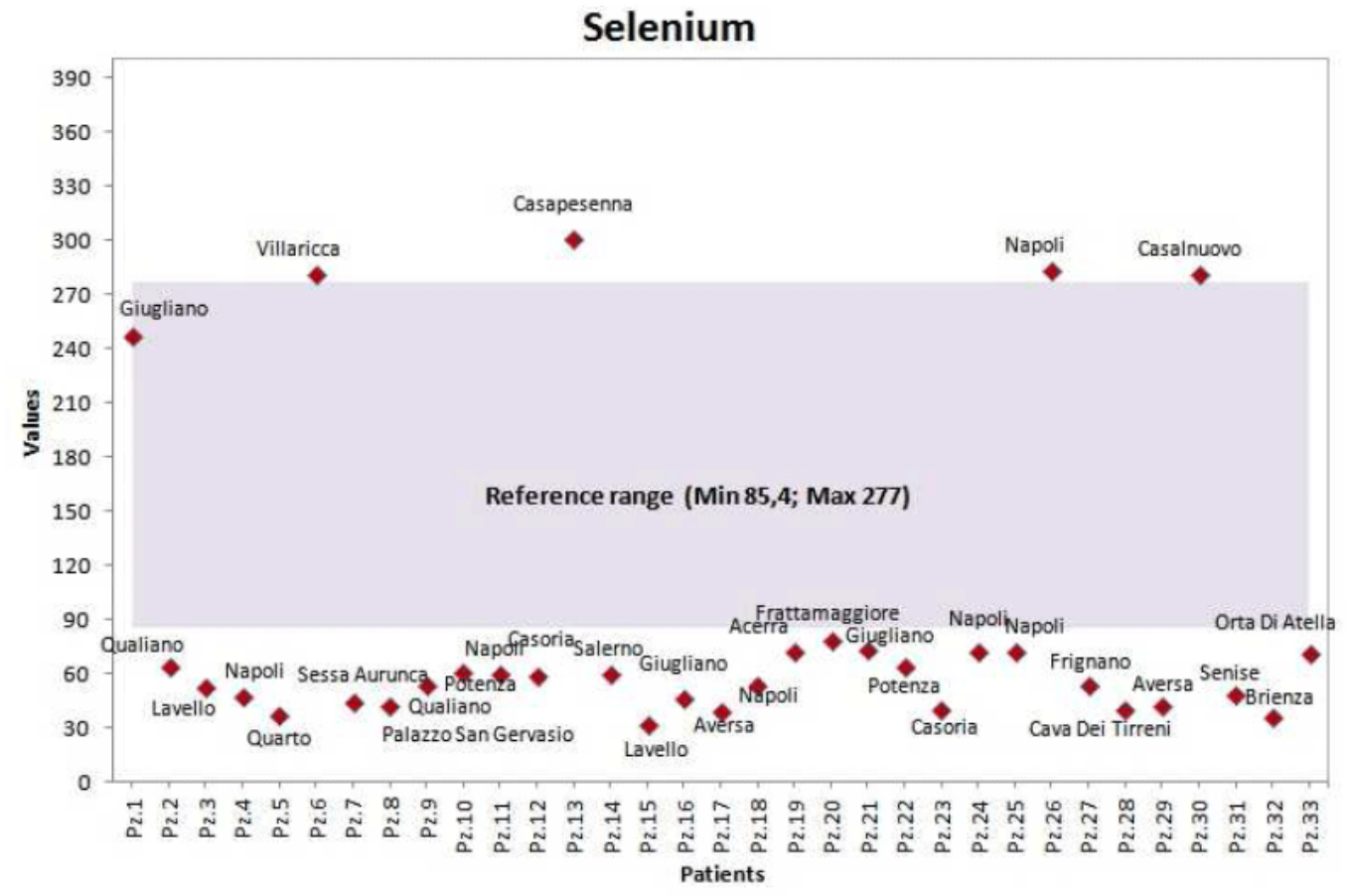

Figure 13: 


\section{Strontium}

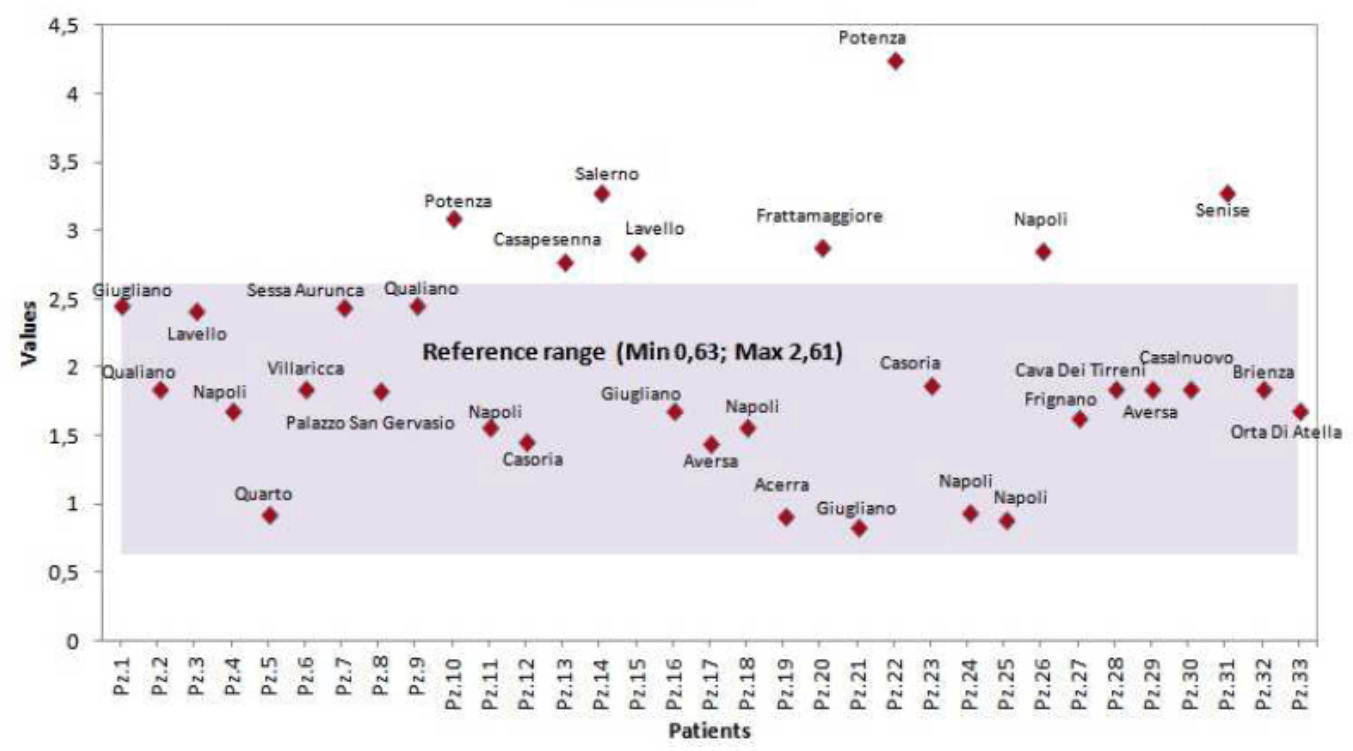

Figure 14:

\section{Discussion}

The matrix, in which the measurements of heavy metals and PCBs are performed, should be an easily accessible biological material, available in sufficient quantities under normal conditions [17], whose sampling is as less invasive as possible and, in any case, does not pose any health risk for the patient. A matrix with these characteristics is ideal for routine and large-scale surveys and for the investigation of particular populations (children, pregnant women, elderly or sick people), where sampling is more subject to ethical and practical limitations [18].

In this study, we used both blood and hair matrices to determine the presence of any potential differences. Hair matrix is used by many companies selling food supplements, or by private laboratories performing the so-called "mineralograms", a popular "trend" that have apparently spread all over the world [16]; this should provide information on medium and long-term exposure to pollutants.

However, hair is more susceptible to changes and external contamination, for example, due to the use of shampoos, conditioners, dyes and other products. False indications are therefore possible, and also minimum and maximum limits are less well established and less standardized (for some metals, the determinations are not well-defined).

In view of the above, we do not believe this matrix is very reliable. Moreover, we think that multiple biological matrices should be analyzed to obtain valid indications. In some cases, it would be appropriate, as done in some studies, to determine these substances in the same neoplastic tissue [1], and maybe compare these findings with those obtained in other matrices (blood, hair, urine) and in the external environment. Importantly, a growing number of studies worldwide increasingly suggest the possibility of a significant causal relationship between onset of cancer (but also of malformations, male infertility and other neurodegenerative, cardiovascular and endocrine disorders) and exposure to heavy metals, PCBs and other chemical substances.

Here, we performed a series of analyses on two biological matrices in a number of patients suffering from oncological disease and living for at least 10 years in areas generally considered at risk of environmental pollution, either accidental or intentional. As far as we know, there are not many studies worldwide that have performed the same analyses on two biological matrices, measuring both heavy metals and this panel of 12 PCBs. Recently, a group of researchers assessed the levels of copper, zinc, lead, chromium and nickel (heavy metals) in breast cancer tissue [1].

Another group of researchers recently published a study in which they measured the concentrations of 10 metals in the hair of patients with head and neck tumors. These researchers assessed the levels of lead, iron, magnesium, zinc, selenium, copper, manganese, calcium and cobalt, but not of all metals and all known heavy metals, reaching the conclusion that the presence of high levels of metals in the blood can be associated with ongoing pathological processes [18].

Exposure to lead, arsenic, cadmium, chromium, zinc and copper can impair many functions of the body, and continuous exposures can lead to carcinogenesis [2, 16-20]. Lead, for example, can bioaccumulate in the body affecting many organs and systems. Furthermore, lead is a mutagenic agent, reportedly due to its lipid peroxidation activity.

In our study, all patients with neoplastic disease had some amount of PCBs in their blood, as well as increased levels of some metals, at least two to three times higher than the maximum reference value. All patients either come from highly urbanized 
areas or from areas with known environmental threats resulting from past or current waste disposal, either intentionally or accidentally. The data of the 10 breast cancer patients are particularly interesting in this respect. These findings seem perfectly in line with the results by Wielsøe et al., who measured the levels of PCBs in cancer patients, concluding that there are "positive associations between breast cancer risk and PCBs and PFAAs" in the environment [3], and with the results by Romaniuk et al., who came to the conclusion that heavy metals, through different routes, stimulate the progression of breast cancer and reduce its sensitivity to treatment [1]. Our preliminary pilot study unquestionably demonstrates that cancer patients living in areas at risk have higher concentration of heavy metals and some PCBs. However, the real impact of these substances and their intimate role in oncogenesis is still a subject of study. Indeed, further studies, specifically comparing patients from polluted areas with those from healthy areas, are required to evaluate the role of these substances in cancer development. Even so, taking into account the growing scientific evidence that seem to converge on a number of points, it would be appropriate to limit as much as possible the exposure of the population to these substances. A strong primary prevention approach, and therefore a greater protection of the environment in which we live and with which we continuously interact, would be desirable. Particular attention must be paid to the disposal of chemical substances. Most likely, we have gone too far and made mistakes that should be addressed. Indeed, the earth and the environment in which we live is like a timeshare property, so we have a moral obligation to leave it clean - after "using" it - for the future generations.

\section{Conclusion}

In this pilot study, we measured the levels of 14 heavy metals and 12 PCBs in the blood and hair samples of 33 cancer patients living in areas considered at risk of pollution.

The levels of most metals were increased - at least three times higher than the maximum reference value - in all studied patients. Interestingly, the highest levels of metals were detected in a patient with testicular seminoma, as well as in patients with ductal carcinoma of the breast. Nevertheless, no correlations were found between the levels of metals and the stage and severity of the cancer disease.

Increased levels of certain PCBs were also found in most patients.

Although the precise role of these substances in carcinogenesis is still unclear, we believe that further studies, specifically comparing patients from polluted areas with those from healthy areas, are required to evaluate their effects on cancer risk at the population level.

\section{References}

1. Romaniuk A, Lyndin M, Sikora V, Lyndina Y, Romaniuk S, Sikora K. Heavy metals effect on breast cancer progression. J Occup Med Toxicol. 2017;12:32. doi: 10.1186/s12995-017-0178-1

2. Kim HS, Kim YJ, Seo YR. An Overview of Carcinogenic Heavy Metal: Molecular Toxicity Mechanism and Prevention. J Cancer Prev. 2015;20(4):232-240. doi: 10.15430/JCP.2015.20.4.232

3. Wielsøe M, Kern P, Bonefeld-Jørgensen EC. Serum levels of environmental pollutants is a risk factor for breast cancer in Inuit: a case control study. Environ Health. 2017;16(1):56. doi: 10.1186/ s12940-017-0269-6

4. Sukdolová V, Negoita S, Hubicki L, DeCaprio A, Carpenter DO. The assessment of risk to acquired hypothyroidism from exposure to PCBs: a study among Akwesasne Mohawk women. Cent Eur J Public Health. 2000;8(3):167-168.

5. Jancic Sa, Stosic Bz. Cadmium effects on the thyroid gland. Vitam Horm. 2014;94:391-425. doi: 10.1016/B978-0-12-800095-3.00014-6

6. Kucharzewski M, Braziewicz J, Majewska U, Gózdz S. Copper, zinc, and selenium in whole blood and thyroid tissue of people with various thyroid diseases. Biol Trace Elem Res. 2003 Summer;93(1-3):9-18.

7. Langer P, Kocan A, Tajtakova M, Petrik J, Chovancova J, Drobna B, et al. Human thyroid in the population exposed to high environmental pollution by organochlorinated pollutants for several decades. Endocr Regul. 2005 Jan;39(1):13-20.

8. Carpenter DO. Polychlorinated biphenyls (PCBs): routes of exposure and effects on human health. Rev Environ Health. 2006;21(1):1-23.

9. IARC monographs on the evaluation of carcinogenic risk to human. Volume 100C. Lyon, International Agency for Research on Cancer. 2012.

10.WHO Regional Office for Europe. Health risks of heavy metals from long-range transboundary air pollution. Copenhagen, WHO Regional Office for Europe. 2007.

11. Chung HK, Nam JS, Ahn CW, Lee YS, Kim KR. Some elements in thyroid tissue are associated with more advanced stage of thyroid cancer in korean women. Biol Trace Elem Res. 2016;171(1):54-62. doi: 10.1007/s12011-015-0502-5

12. Ali H, Khan E. What are heavy metals? Long-standing controversy over the scientific use of the term 'heavy metals'-proposal of a comprehensive definition. Toxicol Environ Chem. 2018;100:6-19. doi: 10.1080/02772248.2017.1413652

13. Tchounwou PB, Yedjou CG, Patlolla AK, Sutton DJ. Heavy metal toxicity and the environment. Exp Suppl. 2012;101:133-164. doi: 10.1007/978-3-7643-8340-4_6

14. Yousaf B, Amina, Liu G, Wang R, Imtiaz M, Rizwan MS, et al. The importance of evaluating metal exposure and predicting human health risks in urban- periurban environments influenced by emerging industry. Chemosphere. 2016;150:79-89. doi: 10.1016/j. chemosphere.2016.02.007 
15. National Toxicology Program. Toxicology and carcinogenesis studies of a binary mixture of 3,3',4,4',5-pentachlorobiphenyl (PCB 126) (Cas No. 57465-28-8) and 2,2',4,4,5,5'-hexachlorobiphenyl (PCB 153) (CAS No. 35065-27-1) in female Harlan Sprague-Dawley rats (gavage studies). Natl Toxicol Program Tech Rep Ser. 2006;(530):1-258.

16. Petrosino V, Motta G, Tenore G, Coletta M, Guariglia A, Testa D. The role of heavy metals and polychlorinated biphenyls (PCBs) in the oncogenesis of head and neck tumors and thyroid diseases: a pilot study. Biometals. 2018;31(2):285-295. doi: 10.1007/s10534-0180091-9

17. Angerer J, Ewers U, Wilhelm M. Human Biomonitoring. State of the art. Int J Hyg Environ Health. 2007;210(3-4):201-228.
18. Wozniak A, Napierala M, Golasik M, Herman M, Walas S, Piekoszewski $\mathrm{W}$, et al. Metal concentrations in hair of patients with various head and neck cancers as a diagnostic aid. Biometals. 2016;29(1):81-93. doi: 10.1007/s10534-015-9899-8

19. Patrick L. Lead toxicity, a review of the literature. Part 1: Exposure, evaluation, and treatment. Altern Med Rev. 2006;11(1):2-22.

20. Hordyjewska A, Popiołek $七$, Kocot J. The many "faces" of copper in medicine and treatment. Biometals. 2014;27(4):611-621. doi: 10.1007/s10534-014-9736-5 